Cornell University Law School

Scholarship@Cornell Law: A Digital Repository

2013

\title{
Between Law and Markets: Is There a Role for Culture and Ethics in Financial Regulation?
}

\author{
Dan Awrey \\ Cornell Law School, aja288@cornell.edu \\ William Blair \\ High Court of England and Wales \\ David Kershaw \\ London School of Economics
}

Follow this and additional works at: https://scholarship.law.cornell.edu/facpub

Part of the Applied Ethics Commons

\section{Recommended Citation}

Dan Awrey, William Blair \& David Kershaw, "Between Law and Markets: Is There a Role for Culture and Ethics in Financial Regulation?" 38 Delaware Journal of Corporate Law 191 (2013)

This Article is brought to you for free and open access by the Faculty Scholarship at Scholarship@Cornell Law: A Digital Repository. It has been accepted for inclusion in Cornell Law Faculty Publications by an authorized administrator of Scholarship@Cornell Law: A Digital Repository. For more information, please contact jmp8@cornell.edu. 


\title{
BETWEEN LAW AND MARKETS: IS THERE A ROLE FOR CULTURE AND ETHICS IN FINANCIAL REGULATION?
}

\author{
BY DAN AWREY, WILLIAM BLAIR AND DAVID KERSHAW*a
}

The limits of markets as mechanisms for constraining socially suboptimal behavior are well documented. Simultaneously, conventional approaches toward the law and regulation are often crude and ineffective mechanisms for containing the social costs of market failure. So where do we turn when both law and markets fail to live up to their social promise? Two possible answers are culture and ethics. In theory, both can help constrain socially undesirable behavior in the vacuum between law and markets. In practice, however, both exhibit manifest shortcomings.

To many, this analysis may portend the end of the story. From our perspective, however, it represents a useful point of departure. While neither law nor markets may be particularly well suited to serving as "the conscience of the Square Mile, "it may nevertheless be possible to harness the power of these institutions to carve out a space within which culture and ethics-or, combining the two, a more ethical culture-can play a meaningful role in constraining socially undesirable behavior within the financial services industry. The objective of this article is to explore some of the ways which, in our view, this might be achieved.

This exploration takes place across two dimensions. In the first dimension, we hold constant the core internal governance arrangementscorporate objectives, directors' duties, board composition, committee structures, and remuneration policies-within financial institutions. We then examine how the law and markets might be leveraged to engender a more ethical culture in two important areas: bilateral counterparty arrangements and socially excessive risk-taking. More specifically, we examine how "process-oriented" regulation, backed by a credible threat of both public enforcement and reputational sanctions, might be employed with a view to reframing personal ethical choices and fostering a more ethical organizational culture within financial services firms.

"Dan Awrey is a University Lecturer in Law \& Finance at Oxford University and a Fellow of Linacre College, Oxford; Sir William Blair is a Judge of the High Court of England and Wales; and David Kershaw is a Professor of Law at the London School of Economics. The authors would like to thank John Armour, Thomas C. Baxter, Jr., Raj Bhala, Sir Ross Cranston, Justice Randy Holland, and the participants at seminars hosted by University College London and Oxford University for their very helpful comments on earlier versions of this article and Tucker McCarthy for superb research assistance. 
Intuitively, we would expect the success of this strategy to be a function of the incentives generated by existing internal governance arrangements. Lamentably, however, many of these arrangements give primacy to the financial interests of shareholders and managers over those of other stakeholders including, perhaps most importantly, society. In the second dimension, therefore, we examine how we might cultivate a more ethical culture through reforms of the core governance arrangements of financial institutions.

\section{TABLE OF CONTENTS}

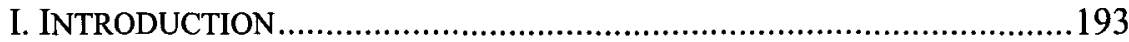

II. THE LIMITS OF LAW AND MARKETS ............................................196

A. The Limits of Markets...........................................................196

B. The Limits of Financial Law and Regulation ..........................198

III. THE ROLE AND LIMITS OF CULTURE AND ETHICS IN FINANCE .......205

A. Making Sense of Culture and Ethics .....................................205

B. The Role and Limits of Ethics................................................207

C. The Role and Limits of Culture in Finance ...............................211

D. Toward a More Ethical Culture in Finance ..............................217

IV. WhO IS MY CliENT? CARVING OUT A ROLE FOR A MORE ETHICAL CULTURE IN BILATERAL COUNTERPARTY RELATIONSHIPS ..................217

A. The TCF Initiative ................................................................2 218

B. The Extended TCF Initiative ...................................................225

V. WhO IS MY NEIGHBOR? CARVING OUT A ROLE FOR A MORE ETHICAL CULTURE IN SYSTEMIC RISK REGULATION.............................227

VI. TREATING BANKS DIFFERENTLY: PRECONDITIONS TO THE EMERGENCE OF BINDING CULTURAL AND ETHICAL CONSTRAINTS .....231

A. Composition Reforms: A Board Level Ethics Committee ..............232

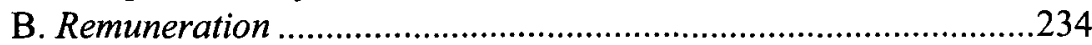

C. Corporate Law: The Objective of Bank Activity ...........................238

D. Corporate Law: Shareholder Rights ...........................................240

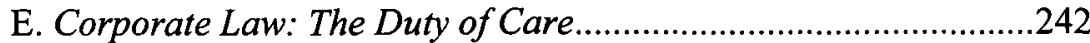

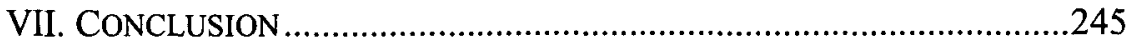




\section{INTRODUCTION}

The limits of markets as mechanisms for constraining socially suboptimal behavior and outcomes are numerous and well documented.' Simultaneously, conventional approaches toward the law and regulation are often crude and ineffective mechanisms for containing-let alone preventing - the social costs of market failure. So where do we turn when both law and markets fail to live up to their social promise? Two possible answers are culture and ethics. ${ }^{2}$ In theory, both can play an important role as extra-contractual or extra-legal gap fillers by helping to constrain socially undesirable activities in the vacuum between law and markets. ${ }^{3}$ In practice, however, the impact of culture as a constraint on socially undesirable behavior is often muted where market participants are numerous, autonomous, and dispersed, and where the interests of market actors diverge. ${ }^{4}$ The internal and subjective nature of ethics, meanwhile, renders their normative content notoriously difficult to reconcile at the individual level-let alone build meaningful consensus around. ${ }^{5}$ We might thus predict that both culture and ethics would prove to be relatively impotent mechanisms for constraining opportunistic behavior, excessive risk-taking, and other socially undesirable activities within the financial services industry. Indeed, this prediction is supported not only by logic, but also experience. From Bankers Trust ${ }^{6}$ and Enron, ${ }^{7}$ to ABACUS, ${ }^{8}$ Libor, ${ }^{9}$ and the

${ }^{1}$ See, e.g., Marion Fourcade \& Kieran Healy, Moral Views of Market Society, 33 ANN. REV. SOC. 285, 291-305 (2007) (summarizing recent theoretical literature).

${ }^{2}$ See infra Part III.A (mapping the distinction between "cultural," "commercial," and other norms, on one hand, and personal "ethics" on the other).

${ }^{3}$ See infra notes 113-16 and accompanying text (synthesizing from empirical research the traits of effective cultural norms).

${ }^{4}$ See infra notes 121-134 and accompanying text (providing evidence of limited behavioral impact of cultural norms in the financial services industry).

${ }^{5}$ See infra note 81 and accompanying text (noting the difficulty of modeling or measuring personal ethics).

${ }^{6}$ See In re Missner, Exchange Act Release No. 33-7124, 34-35136, SEC Docket 1145 (Dec. 22, 1994); In re BT Sec. Corp., CTFC Docket No. 95-3, 1994 WL 711224 (Dec. 22, 1994); BT Securities Censured and Fined \$10 Million for Antifraud and Reporting Violations Relating to the Sales of Derivatives, 94-243 SEC NEwS DIGEST, Dec. 22, 1994, available at http://www.sec.gov/ news/digest/digarchives/digarch 1994.shtml; Kelley Holland, Linda Himelstein \& Zachary Schiller, The Bankers Trust Tapes, BUSINESSWEEK, Oct. 16, 1995, http://www.businessweek.com/1995/ 42/b34461.htm.

${ }^{7}$ See, e.g., BETHANY MCLEAN \& PETER ELKIND, THE SMARTEST GUYS IN THE ROOM: THE AMAZING RISE AND SCANDALOUS FALL OF ENRON 18-21 (2004) (discussing how Enron used profit shifting in hopes of showing "Wall Street that it could produce steadily increasing earnings"); FRANK PARTNOY, INFECTIOUS GREED: HOW DECETT AND RISK CORRUPTED FINANCIAL MARKETS 30 (2003) (recalling how Enron was one of the companies "accused of inflating revenues and 
breaches of U.S. money laundering regulations by HSBC and Standard Chartered ${ }^{10}$ recent financial history is replete with examples of what regulators, politicians, business, and religious leaders have all recognized as, ${ }^{11}$ at least in part, cultural and ethical failures.

To many, this analysis may portend the end of the story. From our perspective, however, it represents a useful point of departure. While neither law nor markets may be particularly well suited to serving as "the conscience of the Square Mile"12 (or Wall Street, Frankfurt or Hong Kong), it may nevertheless be possible to harness the power of these institutions to carve out a space within which culture and ethics-or, combining the two, a more ethical culture $^{13}$ - can be fostered and come to play a meaningful role in constraining undesirable conduct and practices within the financial services

reducing expenses to meet quarterly earnings targets").

${ }^{8}$ See SEC v. Goldman Sachs \& Co., Litig. Release No. 21489 (April 16, 2010), http://www.sec.gov/litigation/litreleases/2010/lr21489.htm; Press Release, U.S. Sec. \& Exchange Comm'n, Goldman Sachs to Pay Record \$550 Million to Settle SEC Charges Related to Subprime Mortgage CDO (July 15, 2010), http://www.sec.gov/news/press/2010/2010-123.htm; Press Release, Fin. Servs. Auth., FSA Fines Goldman Sachs Int'l 117.5 Million for Weaknesses in Controls to Provide FSA with Appropriate Info. (Sept. 9, 2010), http://www.fsa.gov.uk/library/communication/ pr/2010/141.shtml.

${ }^{9}$ See Press Release, Fin. Servs. Auth., Barciays Fined 159.5 Million for Significant Failings in relation to LIBOR and EURIBOR (June 27, 2012), http:/www. fsa.gov.uk/library/communication /pr/2012/070.shtml; Press Release, U.S. Commodity Futures Trading Comm'n, CFTC Orders Barclays to Pay $\$ 200$ Million Penalty for Attempted Manipulation of and False Reporting Concerning LIBOR and Euribor Benchmark Interest Rates (June 27, 2012), http://www.cftc.gov/PressRoom/PressReleases/pr6289-12; Press Release, U.S. Dep't of Justice, Barclays Bank PLC Admits Misconduct Related to Submissions for the London Interbank Offered Rate and the Euro Interbank Offered Rate and Agrees to Pay $\$ 160$ Million Penalty (June 27, 2012), http:/www.justice.gov/opa/pr/2012/June/12-crm-815.html.

${ }^{10}$ See HSBC's Grilling: What Comes Out in the Wash, THE ECONOMIST, July 21, 2012 , http://www.economist.com/node/21559349; Jessica Silver-Greenberg, British Bank in \$340 Million Settlement for Laundering, N.Y. TIMES, (Aug. 14, 2012), http:/www.nytimes.com /2012/08/15/business/standard-chartered-settles-with-new-york-for-340-million,html?pagewanted =all\&_moc.semityn.www.

${ }^{11}$ See infra note 149; see also Emiliya Mychasuk, Money and Morals, FiN. TrMEs (London), Oct. 24, 2009, at 13 (reporting on a seminar for financial sector leaders conducted by the Archbishop of Westminster); Jonathan Sacks, Has Europe Lost its Soul to the Markets?, TTMES (London), Dec. 12,2011 , at 22 (arguing to revitalize Judeo-Christian foundations of markets to develop an ethical culture). See generally WILLIAM BLAIR, STANDARDS AND THE RULE OF LAW AFTER THE GLOBAL FINANCIAL CRISIS in INTERNATIONAL MONETARY AND FINANCIAL LAW: THE GLOBAL CRISIS 97 (Mario Giovanoli \& Diego Devos eds., 2010) (suggesting that the "governance of the international financial system will lack the necessary ethical underpinning to enable real progress to higher standards").

${ }^{12}$ Howard Davies, Chairman, Fin. Servs. Auth., Are Words Still Bonds; How Straight is the City?, Address Before the Securities Institute Ethics Committee: 3rd Annual Lecture (Nov. 2, 1998), available at http://www.fsa.gov.uk/library/communication/speeches/1998/sp18.shtml.

${ }^{13}$ As described in greater detail in Part IV, our use of the term "ethical culture" is motivated by the inherent "chicken and egg" problem vis-à-vis culture and ethics. 
industry. The objective of this article is to explore some of the ways in which, in our view, this might be achieved.

This exploration takes place across two dimensions. In the first dimension, we hold constant the core internal governance arrangementscorporate objectives, directors' duties, board composition, shareholder rights, and remuneration policies-within financial institutions. We then examine how regulation and markets might be leveraged to help engender a more ethical culture in two important areas: (1) bilateral counterparty arrangements and (2) socially excessive risk-taking. More specifically, we examine how so-called "process-oriented"14 regulation, backed by a credible threat of both public enforcement and market-based reputational sanctions, might be employed with a view to reframing personal ethical choices and fostering a more ethical organizational culture within financial services firms.

Intuitively, we would expect the success of this strategy to be a function of the incentive structures generated by the existing constellation of internal governance arrangements. ${ }^{15}$ Put simply, for ethical frameworks to have traction within organizational culture and decision-making they must be given room to breathe. Yet the existing governance arrangements within financial institutions in many jurisdictions directly or indirectly (to differing degrees) give primacy to the financial interests of shareholders and, thereby, create incentive structures which reward opportunistic behavior and socially excessive risk-taking. ${ }^{16}$ These incentive structures are likely to crowd out efforts to foster the formation of a more ethical culture. ${ }^{17}$ In the second dimension, therefore, we examine how we might cultivate a more ethical culture through reforms of the core governance arrangements of financial institutions. $^{18}$

This Article proceeds as follows: Part III maps out the limits of both law and markets as mechanisms for governing conduct within the financial services industry. Part IV then draws out the important distinction between cultural, commercial, and other norms on the one hand, and personal ethics case study).

${ }^{14}$ See discussion infra Part III.A (explaining process-oriented regulation and applying it to a

${ }^{15}$ See infra note 140 and accompanying text.

${ }^{16}$ See infra notes 228-231 and accompanying text explaining why in financial institutions in particular shareholder primacy generates these problematic effects. Generally, on variation in governance arrangements, see e.g., Sofie Cools, The Real Difference in Corporate Law Between the United States and Continental Europe: Distribution of Powers, 30 DEL. J. CORP. L. 697, 762 (2005).

${ }^{17}$ See infra notes $141-45$ and accompanying text.

${ }^{18}$ There is a third dimension, albeit one which resides beyond the scope of this paper, dealing with structural reforms such as ring fencing and narrow banking. 
on the other, to examine the circumstances in which in theory, each is likely to act as a meaningful behavioral constraint. It also articulates the substantive content-essentially a norm of "other regarding" behavior--animating the more ethical culture we seek to foster. Building on this examination, Part V explores how it may be possible to generate more powerful cultural and ethical constraints within the context of bilateral counterparty relationships. The springboard for this examination will be the U.K.'s "Treating Customers Fairly Initiative" ("TCF"), a process-oriented regulatory strategy designed to influence organizational culture surrounding the provision of retail financial services. Part $\mathrm{V}$ also examines the merits and potential drawbacks of expanding the TCF Initiative to encompass transactions involving more sophisticated market counterparties. Part VI then examines whether it may be possible to employ similar process-oriented strategies to cultivate constraints on socially excessive risk-taking. As we shall see, the collision of culture, ethics, and systemic risk raise a host of unique and difficult-to-navigate questions. Finally, moving to the second dimension, Part VII examines why it might be necessary to reconfigure the core internal governance arrangements within financial institutions as a precondition to the emergence of meaningful cultural and/or ethical constraints, and how we might go about doing so.

Ultimately, this paper does not profess to have all the answers. Rather, it aspires to ask some important and often neglected questions about the role of culture and ethics in financial regulation and to offer up a framework for more serious and rigorous discussion.

\section{THE LIMITS OF LAW AND MARKETS}

\section{A. The Limits of Markets}

Markets are good at many things. Most importantly, the price mechanism aggregates and conveys valuable information to market participants about the prevailing supply and demand dynamics for a given asset (along with available substitutes). This information then influences how these market participants allocate scarce resources and, through their decisions, the direction of the broader economy. ${ }^{19}$ Where markets are complete and perfectly competitive, the prevailing view is that the frictionless operation of the price mechanism can be expected to yield a

\footnotetext{
${ }^{19}$ See infra notes $21-22$.
} 
Pareto-efficient equilibrium. ${ }^{20}$ This is the essence of Friedrich Hayek's "spontaneous ordering."21 It is also the theoretical foundation of arguments which view free and unfettered markets as the optimal means of allocating society's resources. ${ }^{22}$

In reality, of course, complete and perfectly competitive markets exist only in textbooks. Markets have limits. These limits (or market failures) are encountered where: information is costly and asymmetrically distributed; competition is imperfect; the existence of public goods results in underinvestment; and where markets generate negative externalities imposing costs on third parties. Perhaps nowhere are these limits more clearly reflected than in the circumstances and events which culminated in the recent global financial crisis (the "GFC"). In many cases, the complexity of modern financial markets overwhelmed the powerful incentives of even the most sophisticated market participants to ferret out and trade on new information. ${ }^{23}$ For example, as Gary Gorton has observed, many market participants did not fully understand how the unique structure of sub-prime mortgages (i.e., their short duration, step-up rates, and pre-payment penalties) made the MBS and CDOs into which they were repackaged particularly sensitive to volatility in underlying home prices. ${ }^{24}$ Along a similar vein, Coval, Jurek, and Stafford have demonstrated how ratings agencies and other market participants failed to perceive both (1) how the structure of $\mathrm{CDOs}$ (and so-called $\mathrm{CDO}^{2}$ ) amplified initial errors with respect to the calculation of default risk on underlying assets, and (2) the systematic interconnections between these assets. ${ }^{25}$ Perhaps more importantly, however, socially excessive private risk-taking - driven by, inter alia, information

${ }^{20}$ See Kenneth-Airow \& Gerard Debreu, Existence of an Equilibrium for a Competitive Economy, 22 ECONOMETRICA 265, 265 (1954). An allocation of resources among two or more parties is said to be "Pareto efficient" where no party can be made better off without making at least one party worse off. Id.

${ }^{21}$ See FRIEDRICH A. HAYEK, IndividuALISM AND ECONOMIC ORDER: THE USE OF KNOWLEDGE IN SOCIETY 86 (1948) ("The whole acts as one market, not because any of its members survey the whole field, but because their limited individual fields of vision sufficiently overlap so that through many intermediaries the relevant information is communicated to all.").

${ }^{22}$ See $i d$. at 77-81.

${ }^{23}$ See, e.g., Robert P. Bartlett, III, Inefficiencies in the Information Thicket: A Case Study of Derivative Disclosures During the Financial Crisis, 36 J. CoRP. L. 1, 57 (2010) (demonstrating how high information costs and low salience of information lead market participants to overlook valuable trading opportunities).

${ }^{24} \mathrm{See}$ Gary Gorton, The Panic of $2007,20-34$ (Aug. 4, 2008), available at http $/ / w w w . k c$. frb.org/publicat/sympos/2008/gorton.08.04.08.pdf.

${ }^{25}$ See Joshua Coval, Jakub Jurek \& Erik Stafford, The Economics of Structured Finance, 23 J. OF ECON. PERSP. 3, 23 (2009). 
problems, ${ }^{26}$ the status of liquidity and financial stability as public goods, ${ }^{27}$ and the moral hazard and competitive distortions created by the so-called "too big to fail" ("TBTF") subsidy ${ }^{28}$ - generated huge negative externalities, the effects of which are still reverberating throughout the global economy. It should come as no surprise then that much of the post-GFC policy debate can be distilled to a single question: what should we do when markets fail to function effectively?

\section{B. The Limits of Financial Law and Regulation}

When markets fail we instinctively reach for the regulatory toolbox to directly address the identified failings. If counterparties are uninformed, we seek to ensure that they receive more information; if certain activities are associated with excessive risk-taking, we seek to separate those activities from core banking functions; if private governance arrangements, such as Libor, are broken, we seek to fix them through public regulatory intervention. Although such reforms are important, we need to be cognizant of the limits of conventional legal and regulatory approaches as tools for directly addressing these market failures.

As a preliminary and general matter, both public choice and regulatory capture theory predict that the law may be shaped by powerful vested interests with little or no regard for broader social welfare. ${ }^{29}$ Indeed, to many, these predictions have considerable explanatory power in the context of the pre-and post-crisis regulation of the financial services industry. ${ }^{30}$ At the same time, we must not assume the omniscience of public

\footnotetext{
${ }^{26}$ See supra notes $23-25$.

${ }^{27}$ See Dirk Schoenmaker, The Financial Trilemma 1 (Duisenberg Sch. of Fin. - Tinbergen Inst. Discussion Papers No. TI 11-019/DSF 7, 2011), available at http://papers.ssm.com/sol3/ papers.cfm?abstract_id $=1340395$. In turn, we would expect this to lead to underinvestment in the development of risk management infrastructure by both public and private actors.

${ }^{28}$ Translating into the failure of TBTF institutions to fully internalize the costs of their risk-taking. See FSA, THE TURNER REVIEW: A REgULATORY RESPONSE TO THE GLOBAL BANKING CRISIS 95-96 (2009), available at http://www.fsa.gov.uk/pubs/other/turner_review.pdf.

${ }^{29}$ See JAMES M. BUCHANAN \& GORDON TULLOCK, THE CALCULUS OF CONSENT 82, 127 , 242 (1962); George J. Stigler, The Theory of Economic Regulation, 2 BELL J. ECON. \& MGMT. SCI. 3, 11-12 (1971); Kenneth J. Arrow, Social CHOICE AND INDIVIDUAL VALUES 119 (2d. ed. 1963); Duncan Black, On the Rationale of Group Decision-Making, 56 J. POL. ECON. 23, 29 (1948).

${ }^{30}$ Similarly, ostensibly desirable regulation is susceptible to being diluted over time by industry lobbying. See, e.g., Sebastian Mallaby, Sombre Spanish Lessons on Fighting Credit Bubbles, FIN. TIMES (London), June 14, 2012, available at http://www.ft.com (search title) (describing how Spanish dynamic provisioning was watered down in response to industry lobbying); Saule T. Omarova, From Gramm-Leach-Bliley to Dodd-Frank: The Unfulfilled Promise of Section 23A of the Federal Reserve Act, 89 N.C. L. REV. 1683, 1763-65 (2011) (describing the gradual
} 
actors. As the GFC has made clear, public regulators often face acute asymmetries of information and expertise vis-à-vis regulated constituencies. ${ }^{31}$ These asymmetries limit the ability of regulators to effectively identify and monitor the location, nature, and extent of potential risks, or design and implement effective regulatory responses. ${ }^{32}$ As a result, we must maintain a healthy degree of skepticism respecting the policy choices of public actors. ${ }^{33}$

Then there is the structure of law itself. It would be extremely costly in most cases, if not entirely impossible, to articulate legal rules which envision the entire universe of potential future states of the world. ${ }^{34}$ These costs invariably give rise to gaps between what the law says, on the one hand, and what its drafters (freed from the shackles of imperfect information, bounded rationality, and other constraints) would have wanted it to say, on the other. ${ }^{35}$ Simultaneously, legal rules-once established may be are often inflexible. They are also often over- or under-inclusive. ${ }^{36}$ This inflexibility generates opportunities for creative compliance and regulatory arbitrage by actors whose incentives are not aligned with regulatory objectives. ${ }^{37}$ There is also the related prospect that prescriptive legal rules will be rendered anachronistic (or perhaps even harmful) by subsequent developments. ${ }^{38}$ Although broader standards may address some of these problems, their very generality may portend their ineffectiveness-particularly when interpreted by actors whose incentive structures are not aligned with regulatory

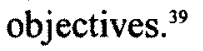

dismantling of section 23A of the U.S. Federal Reserve Act); see also SIMON JOHNSON \& JAMES KWAK, 13 BANKERS: THE WALL STREET TAKEOVER AND THE NEXT FINANCIAL MELTDOWN (2010) (providing an account of how the industry successfully captured lawmakers in the period leading up to the GFC); John C. Coffee, Jr., The Political Economy of Dodd-Frank: Why Financial Reform Tends to be Frustrated and Systemic Risk Perpetuated, 97 CORNEL L. REV. 1019, 1026-27 (2012) (observing similar "downsizing" in connection with the Dodd-Frank Wall Street Reform and Consumer Protection Act, Pub. L. No. 111-203, 124 Stat. 1376 (2010) [hereinafter Dodd-Frank Act $]$ ).

${ }^{31}$ Dan Awrey, Regulating Financial Innovation: A More Principles-Based Proposal?, 5 BROOK. J. CORP. FIN. \& COM. L. 273, 292 n.92 (2011).

${ }^{32}$ See Dan Awrey, Complexity, Innovation and the Regulation of Modern Financial Markets, 2 HARV. Bus. L. REV. 235, 276 (2012)

${ }^{33} \mathrm{See}$ id. at 276-77.

${ }^{34}$ See Awrey, supra note 31, at 277.

${ }^{35}$ See id.

${ }^{36}$ See id. at $292 \mathrm{n} .93$.

${ }^{37}$ See Doreen McBamet, After Enron Will "Whiter than White Collar Crime" Still Wash?, 46 BRIT. J. CRIMINOLOGY 1091, 1092 (2006).

${ }^{38}$ See, e.g., 17 C.F.R. $\$ 270.2 a-7$ (2012) (requiring U.S. domiciled money market funds to only hold debt instruments rated by an NRSRO).

${ }^{39}$ See Mark W. Nelson, Behavioral Evidence on the Effects of Principles- and Rules-Based Standards, 17 ACCT. HORIZONS 91, 93 (2003). 
Two examples will help illustrate the limits of conventional legal and regulatory approaches. Consider first the regulatory strategies typically used to combat potential opportunism stemming from the asymmetries of information and expertise which pervade modern financial markets. The law has historically been utilized in one of three (progressively more invasive) ways to address this problem. The first strategy is to mandate disclosure in an effort to level the informational playing field. ${ }^{40}$ The second strategy is to impose a duty on financial intermediaries to act, to a greater or lesser extent, in the interests of other (less informed) parties. ${ }^{41}$ Strategies falling into this category include both suitability requirements and fiduciary duties. The third strategy includes various forms of product regulation designed, in effect, to insulate less informed parties from risks which they may not fully understand. ${ }^{42}$

While disclosure may be a necessary condition for efficient private contracting, it is often not sufficient. This is due, in no small measure, to the complexity of modern financial markets. ${ }^{43}$ As Robert Bartlett has observed,

${ }^{40} \mathrm{Consider}$, for example, some of the disclosure obligations introduced under the DoddFrank Act. The Dodd-Frank Act requires, for example, that a swap dealer or major swap participant must disclose to any counterparty "information about the material risks and characteristics of the swap" and any conflicts of interest the swap dealer may have. Dodd-Frank Act, Pub. L. No. 111203, § 731, 124 Stat. 1708, 1785 (2010). The Dodd-Frank Act also provides for disclosures by credit rating agencies in relation to credit ratings by authorizing SEC rules requiring filings containing information on, for example, "the assumptions underlying the credit rating procedures and methodologies" and "the data that was relied on to determine the credit rating." Id. § 932, 124 Stat. 1879, 1879 (2010). The SEC's Release on Asset Backed Securities issued in 2010 provides that in relation to structured finance products, the sale agreement for a non-registered private placement gives the purchaser the right to disclosures from the seller that would be available if the offering were registered (on form S-1 or Form SF-1 under the Securities Act of 1933, as am. Pub. Law 112-106). See Asset-Backed Securities, Exchange Act Release Nos. 33-9117, 34-61858, 98 SEC Docket 460 (Apr. 7, 2010).

${ }^{41}$ See FNNANCIAL CONDUCT AUTHORITY, CONDUCT OF BUSINESS SOURCEBOOK $\$ \$ 3,9$ (2013) [hereinafter COBS], available at http://shandbook.info/FS/html/FCA/COBS (discussing client categorization and duty of suitability in the U.K.). With regard to suitability requirements in the United States, see generally Kathleen C. Engel and Patricia A. McCoy, A Tale of Three Markets: The Law and Economics of Predatory Lending, 80 TEX. L. REV. 1255 (2002) and Frederick Mark Gedicks, Suitability Claims and Purchases of Unrecommended Securities: An Agency Theory of Broker-Dealer Liability, 37 ARIZ. ST. L.J. 535 (2005).

${ }^{42}$ This could include: (1) prohibiting the sale of more complex financial products and services to certain informationally disadvantaged parties; (2) mandating simplicity in the structure of these products or services, see David Scharfstein \& Adi Sunderam, The Economics of Housing Finance Reform 53-54 (Harvard Bus. Sch. \& NBER, Working Paper, Aug. 2011), available at http://www.people.hbs.edu/dscharfstein/Economics_of_Housing_Finance_Reform_Brookings.pdf); or (3) implementing ex ante product approval requirements designed to, inter alia, screen out unnecessary complexity, see Saule T. Omarova, License to Deal: Mandatory Approval of Complex Financial Products, 90 WASH. U. L. REV. 63, 68 (2012).

${ }^{43}$ See Awrey, supra note 32, at 237, 242. 
accurately valuing even a single CDO, for example, demands a multi-faceted analysis of an enormous volume of legal and financial data. ${ }^{44}$ The information costs associated with valuing a portfolio of these instruments, Citigroup's balance sheet, or the vast array of intricate and constantly evolving counterparty exposures within the shadow banking system, are clearly orders of a magnitude higher. ${ }^{45}$ Viewed from this perspective, what matters is not just the availability of information in a strictly technical sense, but also the amount and complexity of this information and, consequently, the human capital and other endowments necessary to process it in any meaningful way. ${ }^{46}$ Ultimately, it is the asymmetrical distribution of these endowments which render disclosure, in and of itself, a relatively ineffective strategy for addressing opportunism within the context of bilateral counterparty relationships. ${ }^{47}$

The limits of duty-based strategies stem from the fact that they conflict with the basic tenets of freedom of contract: the notion that individuals are entitled to make their own investment decisions which reflect their (unobservable) preferences. In so doing, such strategies may undermine the allocative efficiency of markets by (1) restricting individual choice and (2) eroding the incentives of investors to engage in information and price discovery. Ultimately, while the resulting costs may be justified where significant asymmetries of information and expertise exist (i.e., in the retail

${ }^{44}$ Bartlett, supra note 23, at 3.

${ }^{45}$ Broadly speaking, the shadow banking system includes:(1) non-bank financial institutions, such as finance companies, structured investment vehicles, securities lenders, money market mutual funds, hedge funds and U.S. government-sponsored entities, and (2) financial instruments, such as repurchase agreements, asset-backed securities, collateralized debt obligations and other derivatives, insofar as these institutions and instruments perform economic functions (i.e., maturity, credit and liquidity transformation) typically associated with more "traditional" banks. See Gary Gorton \& Andrew Metrick, Regulating the Shadow Banking System, Brookings Papers on Econ. Activity, Fall 2010, available at http://www.brookings.edu/ /media/projects/bpea/fall\%202010/2010b_bpea_gor ton; Zoltan Pozsar et al., Shadow Banking (Fed. Reserve Bank of N.Y., Staff Report No. 458, 2010), available at http://www.ny.frb.org/research/staff_reports/sr458.pdf.

${ }^{46}$ See generally Awrey, supra note 32, $242-258$ (discussing the complexity of modem financial markets); see also Complaint If 17, SEC v. Goldman Sachs \& Co., No. 10-CV-3229 (S.D.N.Y. 2010), available at http:/www.sec.gov/litigation/complaints/2010/ comp21489.pdf (referring to the statement of an employee of Paulson \& Co. in relation to Goldman Sachs's structuring of the ABACUS transactions: "It is true that the market is not pricing the subprime RMBS wipeout scenario. In my opinion this situation is due to the fact that rating agencies, CDO managers and underwriters have all the incentives to keep the game going, while 'real money' investors have neither the analytical tools nor the institutional framework to take action before the losses that one could anticipate based [on] the 'news' available everywhere are actually realized.") (emphasis added).

${ }^{47}$ See Awrey, supra note 32 , at 236-37. 
context ${ }^{48}$ ), such strategies are more difficult to justify in contexts involving ostensibly more sophisticated market participants. ${ }^{49}$

The limits of product regulation, meanwhile, are threefold. First, defining ex ante the class of parties deemed to be at an informational disadvantage in respect of a given financial product or service is a difficult and arbitrary task. While the resulting rules may protect less sophisticated parties in many cases, they may also be over-inclusive in their application, arguably impeding the development and spread of new markets for useful products and services. ${ }^{50}$ Second, the very asymmetries of information and expertise product regulation is designed to ameliorate may render the public actors who design and implement these requirements poorly equipped to identify which products and services pose the greatest risks. ${ }^{51}$ Finally, the market distortions generated by these types of requirements have a long history of generating unintended, sometimes even adverse, consequences. ${ }^{52}$

The limits of conventional approaches toward financial law and regulation can also be observed in the current strategies used to address socially excessive risk-taking. ${ }^{53}$ Capital adequacy regulation, for example, has been at the forefront of the post-crisis regulatory response. Yet the crisis

${ }^{48}$ See COBS, supra note $41, \S \S 9.2 .1-.2$ (referring to the U.K.); see also id. $\S 10.2$ (providing an "appropriateness regime" in relation to non-recommended/advised services which is again structured around client knowledge and sophistication); 17 C.F.R. $\S \S 240.10 \mathrm{~b}-3,240.15 \mathrm{c} 2-$ 5 (a)(2) (2012) (focusing on the counterparty's financial situation and needs in the US); Padgett $v$. Dapelo, 826 F. Supp. 99, 100 (S.D.N.Y 1993) (observing the counterparty's level of sophistication and the likelihood that the broker controlled her account); Rolf v. Blyth Eastman Dillon \& Co., 424 F. Supp. 1021, 1026-27 (S.D.N.Y. 1977) (discussing how there was enough evidence to prove that the plaintiff kept careful watch over his securities and that he was not an unsophisticated investor). For a detailed discussion of these provisions, see Engel \& McCoy, supra note 41, at 1258. See also Jonathan Macey et al., Helping Law Catch Up to Markets: Applying Broker-Dealer Law to Subprime Mortgages, 34 J. CORP. L. 789, 815 (2009) (observing that "[t]oday, like in the 1930s, most actions against broker-dealers for suitability and suitability-like violations involve sad stories of elderly and/or infirm individuals swindled by unscrupulous broker-dealers").

${ }^{49}$ See Donald C. Langevoort, Selling Hope, Selling Risk: Some Lessons for Law from Behavioral Economics About Stockbrokers and Sophisticated Customers, 84 CALIF. L. REV. 627, 690 (1996).

${ }^{50}$ Simultaneously, of course, they may be under-inclusive: failing to capture the entire universe of parties in need of protection. See Awrey, supra note 31, at 277.

${ }^{51}$ See Yesha Yadav, The Specter of Sisyphus: Re-making International Financial Regulation After the Global Financial Crisis, 24 EMORY INT'L L. REV. 83, 110 (2010).

${ }^{52}$ See Arnold Kling, Not What They Had in Mind: A History of Policies That Produced the Financial Crisis of 200837 (Mercatus Fin. Mkts. Working Grp., Working Paper No. 1474430, 2009), available at http://mercatus.org/uploadedFiles/Mercatus/Publications/NotWhatTheyHadIn Mind.pdf.

${ }^{53}$ See Robert F. Weber, New Governance, Financial Regulation, and Challenges to Legitimacy: The Example of the Internal Models Approach to Capital Adequacy Regulation, 62 ADMIN. L. REV. 783, 790 (2010). 
itself has revealed the profound limitations of such regulation--limitations that some leading regulators are beginning to publicly acknowledge. ${ }^{54}$ First, the rigid risk weightings employed under the Basel II framework were susceptible to arbitrage by financial institutions using structured finance techniques and their own internal risk models. ${ }^{55}$ While Basel III has removed some of this rigidity, ${ }^{56}$ banks are still able to rely on their own models in assessing asset quality. As a result, arbitrage opportunities still exist. $^{57}$ Yet the obvious alternative is to substitute banks' internal risk assessments for those of bank supervisors: a strategy which was employed by Basel I and subsequently rejected as both inflexible and inaccurate. ${ }^{58}$ Capital adequacy regulation can thus be viewed as involving a choice between two second-best strategies. Second, and partially as a result of these limitations, reported regulatory capital levels are not always an accurate reflection of underlying bank solvency. ${ }^{59}$ For example, just fifteen days prior to filing for bankruptcy, Lehman Brothers reported a Tier 1 capital ratio of $11 \%-7 \%$ higher than the minimum requirement under Basel II.$^{60}$ Similarly, Northern Rock was, on paper at least, the best capitalized major U.K. bank just prior to its demise. ${ }^{61}$

${ }^{54}$ See Brooke Masters, Haldane Calls for a Rethink of Basel HII, FIN. TIMES (London), Aug. 31,2012 , available at $\mathrm{http}: / / \mathrm{www} . f \mathrm{ftcom}$ (search title). Andrew Haldane is the Executive Director for Financial Stability at the Bank of England. Id.

${ }^{55}$ See David Jones, Emerging Problems with the Basel Capital Accord: Regulatory Capital Arbitrage and Related Issues, 24 J. BANKING \& FIN. 35, $42-47$ (2000) (describing how financial institutions utilized structural subordination (i.e., tranching), remote origination (i.e., structured investment vehicles), and indirect credit enhancement (i.e., structured liquidity facilities) to lower their regulatory capital requirements without reducing the underlying economic risk).

${ }_{56}^{5}$ See generally Basel Committee on Banking Supervision, Basel III: A Global Regulatory Framework for More Resilient Banks and Banking Systems; BANK FOR INT'L SETTLEMENTS; 29-54 (June 2011), available at http://www.bis.org/publ/bcbs 189.pdf (outlining "the reforms to the counterparty credit risk framework").

${ }^{57}$ See Brooke Masters et. al., Fears Rise Over Banks' Capital Tinkering, Fin. TIMES (London), Nov. 13, 2011, available at http://www.ft.com (search title) (reporting that "[c]oncern is growing that banks in Europe and elsewhere are moving to meet new tougher capital requirements by tinkering with their internal models to make their holdings appear less risky"); Brooke Masters, Investors Lose Faith in Banks' RWA Models, FIN. TIMES (London), May 23, 2012, available at http://www. ft.com (search title).

${ }^{58}$ See Ines Drumond, Bank Captial Requirements, Business Cycle Fluctuations and the Basel Accords: A Synthesis, 23 J. ECON. SURVs. 798, 807 (2009) (discussing proposed and actual changes to Basel II).

${ }^{59}$ The other distortion being that Basel II (unlike Basel III) did not measure liquidity. See id. at 812

${ }^{60}$ See Candemir Baltali \& Joseph Tanega, Basel III: Dehybridization of Capital, 8N.Y.U. J. L. \& BUS. 1, 15-16 (2011).

${ }^{61}$ Id. at 15. 
Looking forward, it seems almost inevitable that post-crisis reforms such as the U.S. "Volcker Rule," ${ }^{16}$ the U.K.'s retail ring-fence, ${ }^{63}$ and the EU's proposed Liikanen ring-fence, if implemented ${ }^{64}$ will also be vulnerable to regulatory arbitrage. The objective of these reforms is to insulate deposittaking institutions from the risks associated with more speculative investment banking and proprietary trading activities. ${ }^{65}$ At the same time, however, these reforms contemplate that deposit-taking institutions will still be permitted to utilize these instruments for risk management (i.e., hedging) purposes. Yet articulating a comprehensive legal definition of proprietary trading-and distinguishing such trading from permissible hedging activities-is far from straightforward. For a salient example, one need look no further than J.P. Morgan's recent trading loss-estimated to be in the range of two to five billion dollars ${ }^{66}$ - on what was, ostensibly at least, a hedging transaction. ${ }^{67}$ This vulnerability underscores the limits of conventional regulatory approaches to excessive risk-taking.

Much of the financial regulatory toolbox deployed in response to the GFC is therefore limited in its likely effectiveness. Perhaps as important, it is also limited in its outlook. Specifically, these conventional regulatory responses share a common approach to regulation which attempts to dictate or directly influence how market participants act. ${ }^{68}$ They do not, however, attempt to mold how people think when they act. ${ }^{69}$ Put differently, the

${ }^{62}$ See Dodd-Frank Act, Pub. L. 111-203, § 619, 124 Stat. 1376, 1617 (2010) (amending the Bank Holding Company Act of 1956,12 U.S.C. $\$ 1841$ et. seq., to add prohibitions on proprietary trading and certain relationships with hedge funds and private equity funds).

${ }^{63}$ See HM TREASURY, BANKING REFORM: DELIVERING STABILITY AND SUPPORTING A SUSTAINABLE ECONOMY 15 (2012), available at $\mathrm{http}: / / \mathrm{www} . \mathrm{hm}$-treasury.gov.uk/d/whitepaper_ banking_reform_140512.pdf.

${ }^{64}$ See EU High-Level Group on Reforming the Structure of the EU Banking Sector, Final Report EUROPEAN COMM'N, $99 \$ 5.5$ (2012), available at http://ec.europa.eu/internal_market/ bank/docs/high-level_expert_group/report_en.pdf. Whether or not this proposal will be implemented is unclear at the time of writing.

${ }^{65}$ For example, risks involving positions in OTC derivatives. See infra note 111 and accompanying text.

${ }^{66}$ See Lisa Pollack, Oh, So Now It's a \$5bn Loss?, FIN. TIMES BLOG (May 21, 2012, 1:39 PM), http:/ftalphaville.ft.com/blog/2012/05/21/1008231/oh-so-now-its-a-5bn-loss/.

${ }^{67}$ See Shahien Nasiripour \& Tom Braithwaite, JP Morgan Faces Fresh Probe, FIN. TIMES (London), Sept. 6, 2012, available at http://www.ft.com/intl/cms/s/0/5f418ff4-f84a-1 lel-bec800144feabdc0.html (reporting the statement from Senator Carl Levin that the "'enormous loss' was 'just that latest evidence that what banks call hedges are often risky bets"'); see also Standard Chartered Bank v. Ceylon Petroleum Corp., [2011] EWHC (Comm) 1785 (Eng.) (illustrating how difficult it can be to distinguish between speculation and hedging, even following a trial), aff $d$, [2012] EWCA (Comm) 1049 (Eng.) (noting an arbitral tribunal reached a different conclusion on similar facts in a claim by Citibank).

${ }^{68}$ See infra notes $238-39$ and accompanying text.

${ }^{69}$ See infra Part III.A. 
conventional regulatory toolbox does not seek to engender the formation of cultural norms or to frame personal ethical decisions as a means of conditioning behavior.

We now turn to the question of whether culture and/or ethics can help fill the gap inevitably left by law and markets, and whether regulation can be used to enhance the formation and effectiveness of these behavioral constraints. $^{70}$

\section{THE ROLE AND LIMITS OF CULTURE AND ETHICS IN FINANCE}

\section{A. Making Sense of Culture and Ethics}

We are sympathetic to the view reflected in Andrew Hill's statement-"when I hear the words corporate culture, I reach for my pistol ${ }^{171}$ - that culture is an inherently slippery concept. Ethics, if anything, is even more elusive. Framing policy debates around seemingly inchoate concepts like culture and ethics is thus often, and understandably, viewed as somewhat impractical. ${ }^{22}$ Nevertheless, we also know that culture and ethics are important determinants of human and organizational behavior. As a starting point, some degree of definitional precision is thus required. What do we mean in the present context by "culture" and "ethics"? And, importantly, on what basis should we distinguish between these two seemingly intertwined (and yet often muddled) concepts?

Robert Ellickson provides us with a useful framework for thinking about these questions. ${ }^{73}$ Ellickson draws a distinction between first, second, and third-party behavioral constraints. ${ }^{74}$ First-party constraints are imposed

${ }^{70}$ Paul A. Volcker, former chairman of the Federal Reserve and the Economic Recovery Advisory Board, recognized the importance of organizational culture in filling this gap in proposing his "Volcker Rule." See Letter from Paul A. Volcker to U.S. Dep't of Treasury, Fed. Reserve Bd., Fed. Deposit Ins. Corp., Secs. \& Exch. Comm'n, Commodity Futures Trading Comm'n (Feb. 13, 2012), available at http://www.federalreserve.gov/SECRS/2012/February/20120216/R-1432/R1432_021312_105358_329618485095_1.pdf.

${ }^{7}$ Andrew Hill, Culture Questions for Goldman's Blankfein, FIN.TIMES BLOG (Mar. 14, 2012, 1:05 PM), http://www.ft.com (search title).

${ }^{72}$ See Sebastian Mallaby, Woodrow Wilson Knew How to Beard Behemoths, FIN. TIMES (London), July 6, 2012, http://www.ft.com (search title) (observing that "[w] hen policy debates are dominated by the c-word, you know we are out of practical ideas").

${ }^{73}$ See ROBERT C. ELLICKSON, ORDER WTHHOUT LAW: HOW NEIGHBORS SETTLE DISPUTES $123(1991)$.

${ }^{74}$ Id. at 126-27 (employing "controllers" terminology to describe these constraints). 
by an actor on him or herself. This is the domain of "personal ethics."75 Second-party constraints are those which flow from systems of reward and punishment within the context of bilateral relationships between promisors and promisees. This, in turn, is the domain of "contract."76 Third-party constraints, meanwhile, are imposed and administered by actors (i.e., organizations and governments) or social forces (i.e., norms) which, in a strictly technical sense, reside outside the perimeter of such contractual relationships. ${ }^{77}$ Culture-understood as the body of non-legal norms, conventions, or expectations shared by actors when operating in social or institutional settings-can thus be viewed as one subspecies of third-party behavioral constraints. ${ }^{78}$

Culture, ethics, and the law can thus all be viewed as mechanisms - empty vessels - through which various substantive norms are generated, monitored, and enforced. The substantive content of cultural norms and ethics (or, indeed, the law ${ }^{79}$ ) may be identical. The prohibition against the taking of human life, for example, exists across all three dimensions. But equally, cultural, ethical, and legal norms may come into conflict with one another. The key distinction for our purposes is the source of the behavioral constraint and, ultimately, the impact this has on its potential efficacy. In the case of culture and the law, the constraint is an external or exogenous one. In the case of personal ethics, by contrast, it is internal, or endogenous. ${ }^{80}$

${ }^{75} I d$. at 126 .

${ }^{76} \mathrm{Id}$.

${ }^{77}$ See ELLICKSON, supra note 73 , at 127. Although even this distinction is incomplete insofar as membership in many organizations is often contractual in nature.

${ }^{78} \mathrm{We}$ deviate from Ellickson's framework slightly in that we henceforth include constraints generated by private (i.e., non-state) organizations as falling into the category of "norms," whereas Ellickson categorizes them as "organizational rules". See id. This change is merely to facilitate exposition and not to deny the importance of broader questions surrounding what institutions should or should not be understood as sources of the law. Moreover, this approach is consistent with that employed in the economic literature exploring the generation, monitoring, and enforcement of norms by groups of private actors. See infra Part IV.C. Note also that this distinction between first party and third party constraints has an affinity with sociological and legal sociological approaches that posit the radical separation between individual norms and rules and collective or systemic rules and constraints. See, e.g., EMILE DuRkheim, The Rules OF Sociological METHOD 110-12 (Steven Lukes ed., W.D. Halls trans. 1982) (distinguishing between individual and collective representations); NIKLAS LUHMANN, ESSAYS ON SELF REFERENCE 24 (1990) (distinguishing between psychic and communicative systems); Gunther Teubner, How the Law Thinks: Toward a Constructivist Epistemology of the Law, 23 L. \& SOC'Y REV. 727, 732 (1989) (distinguishing between "psychic intentions" and "social communication").

${ }^{79}$ Although, as we have seen, the law can be an inflexible tool for articulating this content. See supra Part II.B.

${ }^{80}$ Ultimately, of course, it is difficult to unpack which factors are either exogenous or 
This, of course, raises an important set of questions: to what extent can cultural norms (or the law) be understood as simply reflecting "shared ethics"? Conversely, what impact do external behavioral constraints, such as cultural norms or the law, have on our internal ethical perspective? Put differently: to what extent do law and culture mold our ethical identity? In the discussion that follows, we largely bracket these questions and use the term "ethical culture" where possible, to signify that culture and ethics can be employed as symbiotic, mutually re-enforcing constraints. Before we articulate the substantive content of this "other regarding" ethical culture, however, it is useful to first canvas the role and limits of both ethics and culture as potential drivers of human and organizational behavior.

\section{B. The Role and Limits of Ethics}

The source of ethical constraints is endogenous to each individual actor: part of that individual's identity. Ultimately, it is this internal orientation-along with the inherent subjectivity and unobservability of first-party enforcement-which renders the behavioral impact of ethics difficult to model in theory and measure in the real world ${ }^{81}$ For some, ethics may provide a powerful guide for personal and professional conduct. For others, it may be dominated by other competing influences. For others still, it may, like Oliver Wendell Holmes' "bad man," 82 not play the slightest role. Moreover, even within these (somewhat artificial ${ }^{83}$ ) categories there exist substantial problems of inter-personal and inter-temporal comparison. This, in turn, makes it difficult to identify "shared ethics". It also raises the prospect that, even at the individual level, ethical perspectives may vary over time and across contexts. ${ }^{84}$

endogenous when attempting to identify the determinants of behavior. Moreover, while something like culture might be exogenous to an individual, it can be seen as endogenous to the organization or group of which that individual is a member.

${ }^{81}$ Although this is precisely what the field of neuro-ethics attempts to do. See generally EDWARD O. WILSON, THE SOCIAL CONQUEST OF EARTH (2012) (espousing theories of evolutionary ethics).

${ }^{82}$ Mr. Oliver Wendell Holmes, Jr., Justice, Supreme Judicial Court of Mass., Address at the Dedication of the New Hall of the Boston University School of Law: The Path of the Law (Jan. 8, 1897), reprinted in Oliver Wendell Holmes, Jr., The Path of the Law, 10 HARV. L. REV. 457, 45961 (1897) (stating that "a [bad] man who cares nothing for an ethical rule which is believed and practised by his neighbors is likely nevertheless to care a good deal to avoid being made to pay money, and will want to keep out of jail if he can").

${ }^{83}$ Both in the sense that (1) the influence of ethics on the behavior of individual actors is perhaps best measured along a spectrum and (2) we might expect actors to fall into different groups at different times and in different contexts.

${ }^{84}$ See MiCHAEL J. SANDEL, WHAT MONEY CAN'T BUY: THE MORAL LIMTTS OF MARKETS 6 (2012) (providing a contemporary discussion about markets). 
The internal nature of ethics also raises a problem for regulation: namely, how can it influence internal ethical perspectives and decisionmaking? Here, ongoing work in the fields of cognitive and social psychology offer some potentially valuable insights. First, the moral intensity (or salience) of an ethical problem can be an important determinant of ethical decision-making. ${ }^{85}$ As Thomas Jones explains, the moral intensity of a problem is a function of, inter alia: (1) the magnitude of the potential consequences; (2) the probability that consequences will occur; (3) their concentration; (4) temporal immediacy; (5) social consensus and; importantly (6) proximity. ${ }^{86}$ Proximity is a measure of the physical, psychological, social, or cultural distance between a decision-maker and those whom their decisions affect. ${ }^{87}$ For example, the anonymity within large, complex organizations, technologies enabling "faceless" communication across great distances, and the commoditization of business transactions and relationships might all be expected to decrease moral intensity ${ }^{88}$ The potential upshot, however, is that by reconfiguring financial institutions and markets with a view to reducing physical or psychological distance, it may be possible to enhance ethical decision-making. ${ }^{89}$

Importantly, the factors identified by Jones as contributing to moral intensity are characteristics of the ethical problem itself, not of decisionmakers..$^{90}$ This, in turn, introduces the prospect that we might be able to reframe elements of the problem so as to highlight their ethical dimensions. The trolley (or footbridge) problem is a paradigmatic example. In the classic formulation of this problem, individuals are asked to participate in a thought experiment in which a train is speeding toward five people tied to the tracks. ${ }^{91}$ Participants are then told that, by pulling a switch, they can redirect

${ }^{85}$ See Thomas M. Jones, Ethical Decision Making by Individuals in Organizations: An Issue-Contingent Model, 16 ACAD. MGMT. REV. 366, 372-74 (1991). Consistent with the relevant cognitive science literature, the terms "moral" and "ethical" (and their various derivations) are used interchangeably in this section.

${ }^{86}$ Id. at 374-78

${ }^{87} I d$. at 376 . Linked to moral intensity is the concept of normative focus: the notion that social or personal norms will only influence behavior if salient at the time of decision-making. See Carl A. Kallgren et al., A Focus Theory of Normative Conduct: When Norms Do and Do Not Affect Behavior, 26 PERSONALITY \& SOC. PSYCHOL. BULL. 1002, 1006 (2000).

${ }^{88}$ See Jones, supra note 85 , at 376 ("Intuitively, people care more about other people who are close to them (socially, culturally, psychologically, or physically) than they do for people who are distant.").

${ }^{89}$ See id. at 376, 387-88; Stanley Milgram, OBEDIENCE TO AUTHORITY: AN EXPERIMENTAL VIEW 33-34 (1974).

${ }^{90}$ Jones, supra note 85 , at 371 .

${ }^{91}$ See JUDITH JARVIS THOMSON, RIGHTS, RESTITUTION, AND RISK: ESSAYS IN MORAL THEORY 94-116 (William Parent ed., 1986); Philippa Foot, The Problem of Abortion and the 
the train onto a second track to which a single person is tied. ${ }^{92}$ In both cases, the person(s) tied to the tracks in the path of the train are certain to perish. ${ }^{93}$ Participants are then asked to consider a second hypothetical in which they are told that the runaway train can be stopped by pushing a man from a footbridge onto the tracks. ${ }^{94}$ Notably, while the welfare implications are identical in each case, experimental evidence suggests that participants (1) experience a stronger emotional response to the second hypothetical and (2) are far less likely to push the man in front of the train than they are to pull the switch.95 The implication, in the view of many, is that by forcing people to directly confront the ethical dimensions of their decisions, it may be possible to make ethics a more powerful influence on behavior.

The second important insight is that contemplation or reflection can enhance ethical decision-making. ${ }^{96}$ Cognitive scientists distinguish between two types of cognitive processes: intuitive processes, in which judgments are made rapidly and automatically (System 1), and controlled processes, in which judgments are slower and more deliberate (System 2). ${ }^{97}$ Several

Doctrine of the Double Effect, 5 OXFORD REV. 1, 2 (1967), reprinted in PHILIPPA FOOT, VIRTUES AND VICES AND OTHER ESSAYS IN MORAL PHILOSOPHY 23 (1978).

${ }^{92}$ See THOMSON, supra note 91 , at 94.

${ }^{93}$ See id.

${ }^{94}$ See id. at 82.

${ }^{95}$ See Piercarlo Valdesolo \& David DeSteno, Manipulations of Emotional Context Shape Moral Judgment, 17 PSYCHOL. SCl. 476, 476 (2006); Joshua D. Greene et al., An fMRI Investigation of Emotional Engagement in Moral Judgment, 293 SCI. 2105, 2106 (2001); Natalie Gold et al., Framing Effects in Ethical Dilemmas: Research Project in Experimental Philosophy (Experimental Ethics) (Arts \& Humanities Research Council Workshop May 3-4, 2012), http://www.le.ac.uk/psychology/amc/ahrc.html (last visited Sept. 26, 2012); see also RICHARD H. THALER \& CASS R. SUNSTEN, NUDGE: IMPROVING DECISIONS ABOUT HEALTH, WEALTH, AND HAPPINESS 19, 54-55 (2008) (discussing framing effects more generally).

${ }^{96}$ See Lawrence Kohlberg, Stage and Sequence: The Cognitive-Developmental Approach to Socialization, in HANDBOOK OF SOCLALIZATION THEORY AND RESEARCH 347 (David A. Goslin ed., 1969); J. Keith Murnighan et al., Bounded Personal Ethics and the Tap Dance of the Real Estate Agency, in ADVANCES IN QUALITATIVE ORGANIZATIONAL RESEARCH 23 (2001); Brian Gunia et al., Contemplation and Conversation: Subtle Influences on Moral Decision Making, 55 ACAD. MGMT. J. 13, 13 (2012). Others, meanwhile, suggest that reflection and reasoning simply serve to generate ex post rationalizations of ex ante moral intuitions. See Jonathan Haidt, The Emotional Dog and Its Rational Tail: A Social Intuitionist Approach to Moral Judgment, 108 PSYCHOL. REV. 814, 814 (2001). Haidt's social intuitionist model, however, is grounded in rightwrong decisions designed to evoke disgust (i.e., incest) on the part of test subjects. See id. at 817. We submit that the vast majority of ethical decisions within the business context do not evoke similar emotions.

${ }^{97}$ See Daniel Kahneman \& Shane Frederick, Representativeness Revisited: Attribute Substitution in Intuitive Judgment, in HEURISTICS AND BIASES: THE PSYCHOLOGY OF INTUITIVE JUDGMENT 51 (Thomas Gilovich et al. eds, 2002); Seymour Epstein, Integration of the Cognitive and Psychodynamic Unconscious, 49 AM. PSYCHOLOGIST 709, 710 (1994); Shane Frederick, Cognitive Reflection and Decision Making, 19 J. ECON. PERSP. 25, 26 (2005); Keith E. Stanovich \& Richard F. West, Individual Differences in Reasoning: Implications for the Rationality Debate?, 23 
scholars have proposed that utilitarian or consequentialist moral judgments take place within System $2 .{ }^{98}$ This view finds empirical support in a recent study by Gunia, Wang, Huang, Wang, and Murnighan, in which test subjects were given three minutes to consider a right-wrong decision-i.e., whether to tell the truth or lie for personal gain-and instructed to "think very carefully" before making their decision. ${ }^{9}$ The authors of the study found that subjects in this contemplation condition were five times more likely to tell the truth than subjects asked to make an immediate decision. ${ }^{100}$ In the view of some scholars, this apparent link between intuitive processes and self-interested decisions reflects deeply engrained evolutionary motives. ${ }^{101}$ Moreover, these motives may dominate in environments such as finance where a premium is placed on quick thinking and decisiveness. ${ }^{102}$ Contemplation, in contrast, allows individuals to consciously weigh ethical considerations against self-interest. ${ }^{103}$ As a result, slowing decision-making processes down and reflecting on their ethical dimensions may yield socially desirable behavioral effects.

Finally, morally-oriented conversations can promote more ethical decision-making in the context of right-wrong decisions pitting values such as honesty against self-interest. ${ }^{104}$ Gunia et al., for example, found that test subjects having even a brief, anonymous, and electronic morally-oriented conversation were four times more likely to tell the truth than subjects having a self-interested conversation. ${ }^{105}$ In effect, conversation can be utilized to highlight the ethical dimensions of problems, enhance moral intensity (or normative focus) and, thereby, put ethical considerations on firmer footing within group decision-making processes. ${ }^{106}$ Simultaneously,

BEHAV. \& BRAIN SCI. 645, 658 (2000); Daniel Kahneman, Nobel Prize Lecture, Maps of Bounded Rationality: A Perspective on Intuitive Judgment and Choice (Dec. 8, 2002), available at http://www.nobelprize.org/nobel_prizes/economics/laureates/2002/kahnemann-lecture.pdf.

${ }^{98}$ See Joshua D. Greene, Why are VMPFC Patients More Utilitarian?: A Dual-Process Theory of Moral Judgment Explains, 11 TRENDS IN COGNITIVE SCI. 322, 322 (2007); Joshua D. Greene et al., The Neural Bases of Cognitive Conflict and Control in Moral Judgment, 44 NEURON 389, 391 (2004); Greene et al., supra note 95, at 2107.

${ }^{99}$ Gunia et al., supra note 96 , at 19-20.

${ }^{100}$ See id. at 22; see also Joseph M. Paxton et al., Reflection and Reasoning in Moral Judgment, 36 COGNITIVE SCl. 163, 171 (2012) (documenting an increased utilitarian moral judgment after inducing people to be more reflective).

${ }^{101}$ See Murnighan et al., supra note 96 , at 20-22.

${ }^{102}$ See Gunia et al., supra note 96 , at 27.

${ }^{103}$ See id. at 15-16.

${ }^{104}$ See id. at $17-18$.

${ }^{105}$ See id. at 24.

${ }^{106}$ See AMITAI ETZIONI, THE MORAl DIMENSION: TOWARD A NEW ECONOMICS 42 (1988). This, of course, works in both directions: conversations which emphasize self-interest may have the opposite effect. See Rebecca K. Ratner \& Dale T. Miller, The Norm of Self-Interest and Its Effects on Social Action, 81 J. PERSONALITY \& SOC. PSYCHOL. 5, 5 (2001). 
however, these conversations must be about more than simply allowing individuals and groups to construct ex post explanations which reinforce their ex ante intuitions. ${ }^{107}$

Ultimately, of course, the insights of cognitive and social psychology must be approached with caution as potential drivers of public policy. ${ }^{108}$ Many strands of this research are still in their theoretical and experimental infancy. Moreover, most of the relevant empirical work has been confined to the laboratory; the real world may confound these predictions. Organizational and other environmental factors may similarly interfere with strategies designed to enhance ethical decision-making. ${ }^{109}$ Nevertheless, as we explore further below, this research may help us better understand ways in which regulation can counteract the emergence of "bad apples" and "bad barrels" within organizations. ${ }^{110}$

\section{The Role and Limits of Culture in Finance}

Few would argue that cultural, commercial, and other extra-legal norms are not capable of exerting a profound influence on human and organizational behavior. Moreover, such norms theoretically offer a number of potential advantages vis-à-vis other behavioral constraints-e.g., the law-in terms of, inter alia, their responsiveness, adaptability, and the relatively low costs of monitoring and enforcement. In markets, these norms can also help overcome the adverse selection and coordination problems which inhibit the development of efficient markets. ${ }^{111}$ Perhaps not surprisingly, therefore, a significant body of scholarship has emerged, dedicated to exploring the precise circumstances in which privately generated norms arise and when they can be expected to yield Pareto improvements over both law and markets. ${ }^{112}$ The majority of this scholarship

\footnotetext{
${ }^{107}$ See Gunia et al., supra note 96 , at 18-19; Haidt, supra note 96 , at 822.

${ }^{108}$ See Ben Seymour \& Ivo Vlaev, Can, and Should, Behovioural Neuroscience Influence Public Policy?, 16 TRENDS IN COGNITIVE SCI. 449, 551 (2012).

${ }^{109}$ See Kallgren et al., supra note 87 , at 1011 ("A variety of situational factors may draw attention to a relevant norm or distract attention from it.").

${ }^{110}$ Neal M. Ashkanasy et. al., Bad Apples in Bad Barrels Revisited: Cognitive Moral Development, Just World Beliefs, Rewards, and Ethical Decision-Making, 16 BUS. ETHCs Q. 449, 451 (2006) ("The 'bad apples' perspective suggests that individual differences affect ethical decision-making and behavior.").

${ }^{11}$ See, e.g., Dan Awrey, The Dynamics of OTC Derivatives Regulation: Bridging the Public-Private Divide, 11 EUR. BUS. ORG. L. REV. 155, 163-64 (2010) (describing how the contractual norms developed by the International Swaps and Derivatives Association helped overcome coordination problems inhibiting the development of OTC derivatives markets).

${ }^{112}$ See Stephen E. Ellis \& Grant M. Hayden, The Cult of Efficiency in Corporate Law, 5 VA.
} 
has centered around homogeneous and geographically proximate groups of market actors-for example, ranchers, ${ }^{113}$ diamond merchants, ${ }^{114}$ and cotton merchants ${ }^{115}$-engaged in long-term, repeat play interactions. Broadly speaking, this scholarship supports the intuition that the most successful norms-i.e., those generating binding behavioral constraints-will be those where: (1) violations are easily observable, (2) news of violations is easily disseminated within the relevant group, and (3) the group possesses both the capacity and incentives to impose immediate and meaningful sanctions on violators. ${ }^{116}$ These factors provide a framework for thinking about the formation of cultural norms not only in the context of market interactions, but also within individual firms.

The financial services industry has produced numerous "codes of conduct," "codes of ethics," and "principles of best practice" which purport to articulate various norms. Prominent examples include the Chartered Financial Analyst (the "CFA") Institute's Code of Ethics and Standards of Professional Conduct, ${ }^{117}$ the Chartered Institute for Securities and Investment's Code of Conduct, ${ }^{118}$ and the Alternative Investment Management Association Guides to Sound Practices. ${ }^{119}$ The salient

L. \& BUS. REV. 239, 241-245 (2010) (explaining the Pareto principal and its relation to corporate governance).

${ }^{113}$ See ELLICKSON, supra note 73, at 1.

${ }^{114}$ See Lisa Bernstein, Opting Out of the Legal System: Extralegal Contractual Relations in the Diamond Industry, 21 J. LEGAL STUD. 115, 115 (1992).

${ }^{115}$ See Lisa Bernstein, Private Commercial Law in the Cotton Industry: Creating Cooperation Through Rules, Norms, and Institutions, 99 MiCH. L. REV. 1724, 1725-28 (2001).

${ }^{116}$ See Bernstein, supra note 114, at 124-30 (discussing the New York Diamond Club's private arbitration system and how it resolves disputes on the basis of trade customs and usages); Bernstein, supra note 115, at 1726-28, 1737-38 (discussing how merchants comply with arbitration decisions of cotton trade associations because failing to do so results in a widely publicized expulsion which affects the profitability of a merchant's business and his reputation); Avner Greif, Contract Enforceability and Economic Institutions in Early Trade: The Maghribi Traders' Coalition, 83 AM. ECON. REV. 525, 525-26, 528-29, 535, 544 (1993) (discussing how the Maghribi's information-transmission mechanism enabled merchants to monitor agents and make cheating known to all, which prevented the agents from acting opportunistically and embezzling trader's goods); ELLICKSON, supra note 73, at 1 (discussing how neighbors in a rural county in California "resolve a variety of disputes that arise from wayward cattle"). In viewing diffusion mechanisms as key to the enforcement of norms, we adopt an individualist rather than an institutionalist approach to norm formation. See Michael Hechter \& Elizabeth Borland, National Self Determination: The Emergence of an International Norm, in SOCIAL NORMS 186 (Michael Hechter \& Karl-Dieter Opp eds., 2001).

${ }^{117}$ Code of Ethics and Standards of Professional Conduct, CHARTERED FIN. ANALYSIS INST. [Code of Ethics], http://www.cfainstitute.org/ethics/codes/ethics/Pages/index.aspx (last visited Sept. 27, 2012).

${ }^{118}$ Code of Conduct, CHARTERED INST. FOR SECS. \& INVS., http://www.siservices.co.uk/ brochures/img_pdf/Code $\% 200$ f $\% 20$ Conduct $\% 202011$ a $\% 20$ without.pdf (last visited Sept. 27 , 2012).

${ }^{119}$ Guides to Sound Practices, ALT. INV. MGMT ASSN, http:/www.aima.org/en/knowledge 
question, however, is whether these norms generate meaningful behavioral constraints across the financial services industry. ${ }^{120}$ Ultimately, this is an important empirical question which resides beyond the scope of this paper. Nevertheless, there exist a number of reasons to suggest that, in a great many cases, the real world impact of these norms may be very limited.

First, as we have already observed, the complexity of modern financial markets is often the source of acute asymmetries of information and expertise. ${ }^{121}$ These asymmetries undermine the ability of market participants with lower tolerances for this complexity to detect violations of any relevant norms, either by their own counterparties, or in the marketplace more generally. ${ }^{122}$ This is especially problematic given that it is precisely these market participants which are, almost by definition, most at risk. In June 2012, for example, the U.K.'s Financial Services Authority ("FSA")-the predecessor to the new Financial Conduct Authority ("FCA")- completed a review which found evidence of widespread misselling of complex interest rate hedging products to relatively unsophisticated small and medium sized enterprises. ${ }^{123}$ Previous FSA reviews have also uncovered extensive mis-selling of, inter alia, payment protection insurance ${ }^{124}$ and sub-prime mortgage products. ${ }^{125}$ The U.S. has similarly experienced a spate of mis-selling claims in the wake of the GFC. ${ }^{126}$ Importantly, this behavior emerged and persisted despite the existence of

_centre/sound-practices/guides-to-sound-practices.cfm (last visited Sept. 27, 2012).

${ }^{120}$ See supra notes $46-47$ and accompanying text.

${ }^{121}$ See supra notes $47-49$ and accompanying text.

${ }^{122}$ See Awrey, supra note 111, 175-77.

${ }^{123}$ See Press Release, FSA, FSA Update, Interest Rate Hedging Products: Information About Our Work and Findings (June 2012), available at http://www.fsa.gov.uk/static/pubs/other/interestrate-hedging-products.pdf. The regulatory structure of banks and financial services in the U.K. has recently been reformed. As of April 1,2013, the existing functions of the FSA in relation to market conduct have been transferred to a new Financial Conduct Authority. See Regulatory Reform Background, FSA, http://www.fsa.gov.uk/about/what/reg_reform/background. Its current prudential regulation function, meanwhile, has been transferred to a new Prudential Regulatory Authority ("PRA"), a subsidiary of the Bank of England. See id.

${ }^{124} \mathrm{See}$ Press Release, FSA, The Sale of Payment Protection Insurance: Results of Thematic Work (Nov. 2005), available at http://www.fsa.gov.uk/pubs/other/ppi thematic_report.pdf; Payment Protection Insurance Market Investigation Order 2011, COMPETTION COMM'N (Mar. 24, 2011), available at http://www.competition-commission.org.uk/ (search title). As of April 2013, f9.3 billion has been paid out in refunds and compensation for mis-sold payment protection insurance. See Monthly PPI Refunds and Compensation, FCA, http://www.fca.org.uk/consumers/ financial-services-products/insurance/payment-protection-insurance/refunds (last visited April. 25, 2013).

${ }^{125}$ See Press Release, FSA, FSA Finds Poor Practices by Intermediaries and Lenders within Sub-prime Market (July 4, 2007), available at http://www.fsa.gov.uk/library/communication/ $\mathrm{pr} / 2007 / 081$.shtml.

${ }^{126}$ See Tom Braithwaite et al., Banks Sued Over Mortgage Deals, FIN. TIMES (London), Sept. 3, 2011, available at http://www.ft.com (search title). 
numerous industry codes and institutional pronouncements stating, in effect, that the customer always comes first. ${ }^{127}$ It did so, at least in part, because the market participants which it targeted were poorly positioned to detect it.

Second, even where violations are observable, there is often no credible threat of enforcement. The CFA Institute's Code of Ethics provides an illustrative example. ${ }^{128}$ The CFA is arguably the most prestigious designation for financial services professionals. The Code of Ethics stipulates that CFA members must act with integrity, diligence, competence, respect and in an ethical manner. ${ }^{129}$ In the context of advisory relationships, it also imposes duties of loyalty, fair dealing, suitability, and disclosure of conflicts of interest. ${ }^{130}$ These important ethical objectives have much in common with those articulated in other professional contexts such as law and accountancy. ${ }^{131}$ The CFA Institute has established a disciplinary procedure to address violations of the Code of Ethics, with its most powerful sanctions being to suspend or revoke a violator's membership. ${ }^{132}$

As an organization whose reputation and financial resources are derived from its ability to attract and retain its members, however, the CFA Institute's incentives to vigorously pursue enforcement action are relatively weak. ${ }^{133}$ This weakness is reflected in the CFA Institute's own enforcement statistics, which report an average of 2.42 suspensions and 0.92 expulsions per year from 2000-2011 from a total membership of over $98,000{ }^{134}$ This

${ }^{127}$ See, e.g., Business Principles and Standards: Golden Sachs Business Principles, GOLDMAN SACHS, http:/www.goldmansachs.com/who-we-are/business-standards/business-princi ples/index.html (last visited Feb. 21, 2013) (stating "[o]ur clients' interests always come first.").

${ }^{128}$ See generally Disciplinary Statistics, CFA INST. (2000-12), available at www.cfainstitute.org/ethics/Documents/Professional\%20Conduct\%20Program\%20Documents/me m_discipline_stats.pdf (illustrating examples and giving guidance on the Standards of day-to-day professional activities).

${ }^{129}$ Code of Ethics and Standards of Professional Conduct, CFA, www.cfapubs.org/doi/ pdf/10.2469/ccb.v2010.n14.1 (last visited Feb. 24, 2013).

${ }^{130}$ See id.

${ }^{131}$ See, e.g., Solicitors Regulatory Authority Handbook, SOLICITORS REG. AUTH. (Oct. 6, 2011), http://www.sra.org.uk/handbook/ (legal standards); Ethical Standards for Auditors, FIN. REPORTING COUNCIL, http://www.frc.org.uk/Our-Work/Codes-Standards/Audit-and-assurance/ Standards-and-guidance/Standards-and-guidance-for-auditors/Ethical-standards-for-auditors.aspx (last visited Feb. 24, 2013) (accounting standards).

${ }^{132}$ See Current Industry-Related Sanctions, CFA INST., available at www.cfainstitute.org/ ethics/conduct/pages/current_industry_related_sanctions.aspx (last visited Feb. 24, 2013). It can also issue, inter alia, cautionary letters, private reprimands and public censures. Id.

${ }^{133}$ See generally Disciplinary Statistics, CFA INST., available at www.cfainstitute.org/et hics/Documents/Professional\%20Conduct\%20Program\%20Documents/mem_discipline_stats.pdf (last visited Feb. 24, 2013) (presenting the lack of enforcement in the statistics of professional conduct cases involving industry matters from 2000-2012).

${ }^{134}$ See id. The figures over the same period for cautionary letters, private reprimands and censures are, respectively, $16.25,5.83$ and 1.17 per year. See id. 
data suggests either that CFA members almost never violate the Code of Ethics or, perhaps more likely, that the probability of detection and subsequent enforcement is extremely low.

Theoretically, the violation of norms can also be enforced within the marketplace itself via the imposition of reputational sanctions. ${ }^{135}$ Once again, however, high information costs can be expected to impede the process by which news of violations is disseminated within the marketplace and, thus, undermine the potency of this market-based enforcement mechanism. ${ }^{136}$ Indeed, even where information costs are relatively low, the mobility (and resulting transience) of personnel within the financial services industry can make it difficult to effectively target reputational sanctions. ${ }^{137}$ Concomitantly, it is not uncommon for market participants to make significant relationship-specific investments in the financial services firms with which they do business. ${ }^{138}$ This, in turn, increases the costs of "exit" in response to the violation of a norm recognized as existing within the context of that relationship and, as a corollary, increases the likelihood of private renegotiation or alternative dispute resolution (as opposed to public litigation) as a means of compensating the aggrieved party for any loss. ${ }^{139}$ Each of these factors is likely to have a dilutive impact on any market discipline which might have otherwise been brought to bear on those market participants perceived to have violated a cultural or commercial norm.

While markets may not provide the most fertile ground for the formation and cultivation of cultural norms, the structure of the firm arguably holds considerably more promise. The frequency of interactions within a firm will often render violations of firm-specific norms (relatively)

${ }^{135}$ See Cindy R. Alexander, On the Nature of the Reputational Penalty for Corporate Crime, 42 J. L. \& ECON. 489, 490-91 (1999); John Armour et al-, Regulatory Sanctions and Reputational Damage in Financial Markets 1 (Oxford Legal Studies Research Paper No. 62/2010, 2012), available at http://papers.ssm.com/sol3/papers.cfm?abstract_id $=1678028 ;$ John R. Graham et al., Corporate Misreporting and Bank loan Contracting, 89 J. FIN. ECON. 44, 46 (2008); Gregg Jarrell \& Sam Peltzman, The Impact of Product Recalls on the Wealth of Sellers, $93 \mathrm{~J}$. POL. ECON. 512, 513 (1985); Jonathan M. Karpoff et al., The Cost to Firms of Cooking the Books, 43 J. FIN. \& QUANTITATIVE ANALYSIS 581, 583 (2008); Benjamin Klein \& Keith Laffler, The Role of Market Forces in Ensuring Contractual Performance, 89 J. POL. ECON. 615, 616 (1981).

${ }^{136} \mathrm{~J}$ Jhn Armour et al., supra note 135, at 11.

${ }^{137}$ See id. How, for example, do you impose effective reputational sanctions in the circumstance where the violation was committed by a team at financial institution " $\mathrm{A}$ ", but where all members of the team are now dispersed among institutions " $B, "$ " $C$," and "D"? And what if the senior management team at " $\mathrm{A}$ " at the time of the violation - who might have notionally been responsible for overseeing the team's activities - have themselves moved on? Where, in this case, is the appropriate locus of the sanction?

${ }^{138}$ Klein \& Keith, supra note 135 , at 616.

${ }^{139}$ Alexander, supra note 135 , at 516-17. 
observable. ${ }^{140}$ Violations of these norms can then be disseminated easily up the firm's hierarchy through formal complaint and compliance procedures, management information systems, as well as by word of mouth. There also exists a range of firm-level disciplinary mechanisms which provide relatively low cost means of sanctioning non-compliance. These mechanisms include, inter alia: dismissal, demotion, promotion (or the denial thereof), quality of work flow, and, of course, remuneration.

The key question for financial services firms is thus not how to generate, monitor, and enforce compliance with cultural norms per se but, rather, how to foster a more ethical culture. While codes of ethics can be drafted and held up as reflective of best practice, the cultural norms these codes purport to reflect may be overpowered by other countervailing cultural norms. Indeed, there is significant anecdotal evidence of such countervailing norms within many financial firms. These norms resemble what Dale Miller has characterized as "the norm of self-interest;"14! a norm reinforced by existing incentive structures. ${ }^{142}$ Notably, "self-interest" in this context may encompass the interests of individual employees, teams, divisions, ${ }^{143}$ or even the entire institution. ${ }^{144}$ Indeed, a prominent diagnosis of recent events-including the Libor, mis-selling, and money-laundering scandals- has been that dysfunctional firm cultures were the primary driver of these failings. ${ }^{145}$

${ }^{140}$ Although, especially within financial services firms, there may be ample scope for agents to hide their non-compliant behavior. This reality is driven home by the "rogue trader" scandals such as Nick Leeson's trading activities at Barings plc.

${ }_{141}$ Ratner \& Miller, supra note 106, at 5.

${ }^{142}$ See Salz Review: An Independent Review of Barclay's Business Practices (2013) at 6 (observing that "[w]e believe that the business practices for which Barclays has rightly been criticised were shaped predominantly by its cultures"), available at $\mathrm{http}$ :/group.barclays.com/aboutbarclays/citizenship/salz-review-report. See also Grant Woods, Barclays Culture Discouraged Staff from Raising Concerns, FIN. TIMES (London), July 10, 2012, available at http://www.ft.com (search title) for anecdotal evidence supporting the view that a culture of individualism is readily enforced within financial services firms. See also id. ("The culture at Barclays in 2006-07, when I worked there, discouraged staff from raising concerns; in some instances, their loyalty and commitment were questioned, should they do so. There was also the unsaid threat that it could adversely affect any potential bonus or, worse, undermine their job security.").

${ }^{143} \mathrm{See}$ Gillian Tett, Insight: Anthropological Insights into Banking Behaviour, FN. TMES (London), Jan. 17, 2008, at 1 (referring to "warring . . tribal cultures" in Citibank and Merrill Lynch).

${ }^{144}$ See id.

${ }^{145}$ See Shaming the Banks into Better Ways: Barclays Affair Shines Unsparing Light on Financial Sector, FIN. TIMES (London), June 28, 2012, at 8 (referring to the "rotten culture at Barclays"). 


\section{Toward a More Ethical Culture in Finance}

So what is the substantive content of the ethical culture this paper aspires to cultivate? As stated at the outset, our dual objectives are to explore ways in which the law and markets might be utilized to engender cultural and ethical constraints on both (1) opportunism in the context of bilateral counterparty arrangements and (2) socially excessive risk-taking. ${ }^{146}$ The common theme underlying both of these objectives is the desire to promote what can best be characterized as a norm of "other regarding" behavior within financial services firms, one which, to the fullest extent possible, attempts to induce firms to take into account the private and social costs of their decisions. ${ }^{147}$ These objectives should not, in our view, be controversial given the enormous social impact of the GFC and the questionable conduct and practices which it has brought to light. Moreover, as described above (and in further detail below) "other regarding" norms are already reflected in many of the codes of conduct, principles of best practice, and other guidance produced by various professional bodies and other organizations. Our objective in this article is to explore whether it might be possible to enhance the behavioral impact of these norms.

\section{WHO IS MY CLIENT? CARVING OUT A ROLE FOR A MORE ETHICAL CULTURE IN BILATERAL COUNTERPARTY RELATIONSHIPS}

Financial policymakers are well aware of the important role culture can play within financial services firms. The Basel Committee on Banking Supervision, for example, has observed that "[a] demonstrated corporate culture that supports and provides appropriate norms and incentives for professional and responsible behavior is an essential foundation of good governance. ${ }^{148}$ Many senior figures within the financial services industry have, similarly, signaled that they are receptive to the idea that culture can

${ }^{146}$ See supra Part II.B.

${ }^{147}$ It is noteworthy in this regard that "other regardingness" is the touchstone used in much of the cognitive science literature as a proxy for "ethical" decision-making and conduct. See Gunia et al., supra note 96 , at 14 .

${ }^{148}$ Principles for Enhancing Corporate Governance, BCBS, 8,22 (Oct. 4, 2010), available at http://www.bis.org/publ/bcbs 176.pdf ("Sound corporate governance is evidenced, among other things, by a culture where senior management and staff are expected and encouraged to identify risk issues as opposed to relying on the internal audit or risk management functions to identify them. This expectation is conveyed not only through bank policies and procedures, but also through the 'tone at the top' established by the board and senior management."). 
play a meaningful role in firm governance. ${ }^{149}$ From the perspective of many policymakers, however, the objective of fostering meaningful cultural and or ethical constraints on socially undesirable behavior is, at best, aspirational. ${ }^{150}$ As a result, while we have seen post-crisis calls for financial services firms to take culture and ethics more seriously, we have not seen substantive policy proposals which would seek to actively promote a more ethical culture in finance.

\section{A. The TCF Initiative}

Nevertheless, there are precedents. One such precedent is an ostensibly modest scheme implemented by the U.K.'s FSA prior to the crisis, known as the Treating Customers Fairly (the "TCF") Initiative. ${ }^{151}$ As its name implies, the objective of the TCF Initiative is to compel financial services firms to treat retail clients fairly. ${ }^{152}$ The first incarnation of the TCF Initiative was introduced in 2001 in response to a raft of mis-selling claims involving various financial products. ${ }^{153}$ Notably, however, the legal obligation on U.K. financial services firms to treat customers fairly predates the TCF Initiative. ${ }^{154}$ The E.U. Markets in Financial Instruments Directive ("MiFID"), for example, mandates that member States require a financial services firm to "act honestly, fairly and professionally in accordance with the best interest of its clients ...."'1ss These requirements are reflected in the

\footnotetext{
${ }^{149}$ See, e.g., STEPHEN GREEN, GOOD VALUE: REFLECTIONS ON MONEY, MORALITY AND AN UNCERTAIN WORLD 198 (2009) (observing that "[e]veryone knows about the importance of trust and honesty for a sustainable business").

${ }^{150}$ See, e.g., Davies, supra note 12 (emphasizing that "it is not for regulators to devise a fullscale ethical code for financial firms"); City's Ethics Awareness Lessons Must Percolate Down, Fin. TIMES (London), October 4, 2010, available at http://www.ft.com (search title) (observing that Hector Sants, former CEO of the U.K.'s FSA, "was told on arrival at the FSA that the regulator 'does not do ethics"').

${ }^{151}$ See Treating Customers Fairly, FSA, http://www.fsa.gov.uk/doing/reg ulated/tcf (last visited January 16, 2013).

${ }^{152}$ See id.

${ }^{153}$ See Sharon Gilad, Overcoming Resistance to Regulation via Reframing and Delegation, in REGULATION \& GOVERNANCE (forthcoming 2012) (manuscript at 9), available at http:/law.huji.ac.il/upload/Sharon.Gilad.pdf.

${ }^{154}$ See Julia Black et al., Making a Success of Principles-based Regulation, 1 LAW \& FIN. MKT. 191, 191 (2007).

${ }^{155}$ Council Directive 2004/39, art. 19(1), 2004 O.J. (L 145/1) (EC). Notably, recently proposed amendments to MiFID would clarify that "the overarching high level principle to act honestly, fairly and professionally and the obligation to be fair, clear and not misleading should apply irrespective of [retail or professional] client categorization." Explanatory Memorandum on Proposed Directive on Markets in Financial Instruments repealing Directive 2004/39/EC of the European Parliament and of the Council, s. 3.4 .8 (October 20, 2011), available at http://eur-
} 
FCA's, as well as its predecessor the FSA's, Principles for Business, which include, inter alia, the requirement to act honestly and with integrity, to treat customers fairly, and to communicate with clients in a way that is fair and not-misleading. ${ }^{156}$ What distinguishes the TCF Initiative from these broader regulatory pronouncements, however, is that firm processes and culture are the targets of regulation.

The TCF Initiative falls under the umbrella of a diverse collection of regulatory strategies, which is often described as "processoriented" regulation. ${ }^{157}$ Process-oriented regulation proceeds from the acknowledgement that "top-down," prescriptive regulation is often ill-suited to heterogeneous and fast-paced industries such as finance, where entrenched asymmetries of information and expertise pervade the relationship between regulators and regulated actors. ${ }^{158}$ The hallmark of process-oriented regulation, then, is that it seeks to leverage the superior information and expertise of regulated actors by granting them the flexibility to design bespoke organizational processes, systems, and controls with a view to achieving a set of broad regulatory objectives (or outcomes) articulated by the regulator. ${ }^{159}$ Simultaneously, however, process-oriented regulation is about more than leveraging firm-specific information to produce tailored systems and controls. Process-oriented regulation is also about incorporating the regulatory objectives (or outcomes) into firm culture. ${ }^{160}$ As Christine Parker observes, process-oriented regulation, which

lex.europa.eu/LexUriServ/LexUriServ.do?uri=COM:2011:0656:FIN:en:PDF; Norton Rose, MiFID Review: Overview, http://www.nortonrose.com/knowledge/publications/57748/mifid-review overview (last visited Jan. 16, 2013).

${ }^{156}$ Financial Services Authority Handbook, Principles for Business, FSA, § 2.1.1 (2001), available at http:// fshandbook.info/FS/html/FCA/PRIN.

${ }^{157}$ See Gilad, supra note 153 , at 27 . Members of this family include "systems-based regulation, enforced self-regulation, management-based regulation, principles-based regulation, and meta-regulation." Sharon Gilad, It Runs in the Family: Meta-regulation and Its Siblings, 4 REG. \& GOVERNANCE 485, 485 (2010).

${ }^{158}$ See JULIA BLACK, RULES AND Regulators 136 (1997); Cass R. Sunstein, Problems with Rules, 83 CALIF. L. REV. 953, 993-94; Gilad, supra note 157, at 488.

${ }^{159}$ See Christine Parker, Meta-Regulation: Legal Accountability for Corporate Social Responsibility, in THE NEW CORPORATE ACCOUNTABIIITY: CORPORATE SOCIAL RESPONSIBILITY AND THE LAW 220, 224 (Doreen McBamet et al., eds., 2008).

${ }^{160}$ See Treating Customers Fairly - Towards Fair Outcomes for Consumers, FSA, 11 (July 2006), available at http://www.fsa.gov.uk/pubs/other/tcf_towards.pdf; see also Julia Black, Forms and Paradoxes of Principles-Based Regulation, 3 CAPITAL MKTS. L. J. 425 (2008) (identifying cultural change as one of the potential advantages of this type of regulation-which she labels "principles-based" regulation-while simultaneously noting some of the drawbacks of giving regulatory authority to regulated constituencies that may have incentives to interpret the outcomes in non-compliant ways); Parker, supra note 159, at 215-16 (stating that the aim for each company would be to have "an organisational culture that supports and sustains responsibility, and that management would be carried out in practice in a way that demonstrates responsibility"). 
she labels "meta-regulation," focuses "on the inside of corporations to constitute corporate consciences that go beyond compliance ...."161

It is important to understand how the TCF Initiative seeks to affect cultural change. Two ideas appear to underpin this process. The first is connected to the preconditions to the formation of cultural norms identified in Part IV: observability, dissemination, and enforcement. ${ }^{162}$ Of central importance in this regard is "tone from the top." ${ }^{163}$ More specifically, a key foundation for cultural change is that senior managers make it clear to the rest of the firm that (1) the regulatory objectives reflected in the TCF Initiative matter, and (2) violations will result in internal sanctions. ${ }^{164}$ Second, both the act of transferring ownership of regulatory responsibility to the firm and the firm's engagement with regulatory objectives engender the formation of norms about expected and legitimate behavior. ${ }^{165}$

In its ideal form, process-oriented regulation promotes dialogue, processes, systems, and controls that generate behavioral norms that are articulated, disseminated, monitored, and enforced by internal mechanisms backed by senior management's imprimatur. ${ }^{166}$ As Parker and Sharon Gilad point out, however, it is improbable that firm culture can be instrumentally created in this way. ${ }^{167}$ Any attempt to foster specified normative positions takes place through agents (including senior management) that may have countervailing normative commitments and incentives and who may, therefore, deploy strategies to resist cultural change ${ }^{168}$ A more realistic way to look at process-oriented regulation is thus as one of several complimentary strategies $^{169}$ designed to increase the probability that certain normative

${ }^{161} I d$. at 211-12. See also id, at 214. ("A corporate conscience is created when values that transcend narrow self-interest are built into the practice and structure of the enterprise.") (quoting PHILIP SELZNICK, THE COMMUNITARIAN PERSUASION 101 (2002)).

${ }^{162}$ See Treating Customers Fairly, supra note 160, at 19-20.

${ }^{163}$ See id. at 11 .

${ }^{164}$ See Black, supra note 158 , at 203.

${ }^{165}$ This view finds support in both organizational and sociological theory. See, e.g., Silbey et al., "The Sociological Citizen" Relational Independence in Law and Organizations, 59 L'ANNÉE SOCIOLOGIQUE 201, 218 (2009) (describing a case study in which project engagement resulted in a "perceptual and moral transformation"); see also Clifford Geertz, Thick Description: Toward and Interpretative Theory of Culture, in THE INTERPRETATION OF CULTURES: SELECTED ESSAYS 17 (1973) (observing that "it is through the flow of behaviour-or, more precisely, social action - that cultural forms find articulation").

${ }^{166}$ See Gilad, supra note 157 , at $486,500$.

${ }^{167}$ Christine Parker \& Sharon Gilad, Internal Corporate Compliance Management Systems: Structure, Culture and Agency, in EXPLAINING COMPLIANCE: BUSINESS RESPONSES TO REGULATION 170, 176-77 (Christine Parker \& Vibeke Lehmann Nielson eds., 2011).

${ }^{168}$ See id, at 180.

${ }^{169}$ See infra Part V (exploring supportive incentive structures). 
positions can be voiced and gain traction within the firm. Put differently, it seeks to bias the internal battleground of firm culture in favor of specified regulatory objectives.

The TCF Initiative proceeds from the identification of six outcomes which the FSA expects financial services firms to achieve on behalf of their retail clients. ${ }^{170}$ These outcomes aim to ensure that: (1) fair treatment of consumers is embedded in corporate culture; (2) products and services meet the needs of identified consumer groups and are targeted accordingly; (3) sufficient information is provided to consumers before, during, and after the point of sale; (4) any advice is suitable to a particular consumer; (5) products and services meet the expectations of consumers; and (6) consumers do not face unreasonable post-sale barriers imposed by firms to change product, switch their provider, submit a claim, or make a complaint. ${ }^{171}$ The FSA has also produced "extensive guidance" about how firms should approach their obligations under the TCF Initiative. ${ }^{172}$ Compliance with the TCF Initiative is then measured against the extent to which the processes designed and implemented by firms are able to deliver against these outcomes. ${ }^{173}$

Consistent with its process-oriented approach, the TCF Initiative compels firms to design and evaluate their own organizational processes against desired regulatory outcomes. ${ }^{174}$ In giving firms the flexibility to design and implement firm-specific processes, the TCF Initiative also shifts at least some of the responsibility for meaningfully engaging with, and ultimately achieving, regulatory objectives from the regulator to regulated firms themselves. ${ }^{175}$ The TCF Initiative places the onus on firms, and specifically on senior management, to promote an organizational culture that encourages meaningful internal dialogue about firm practices, their impact on retail clients, and whether or not they meet the required regulatory outcomes. ${ }^{176}$ Indeed, the FSA describes the TCF Initiative as "a cultural issue, ${ }^{117}$ observing: "[i]t is only through establishing the right culture that

${ }^{170}$ See Treating Customers Fairly - Guide To Management Information, FIN. SERVS. AUTH., 11 (July 2007), available at http://www.fsa.gov.uk/pubs/other/tcf_mi.pdf.

${ }^{171}$ Id. at 11-13.

${ }^{172}$ See Gilad, supra note 157, at 14-15; Guide to Management, supra note 170 , at 3.

${ }^{173}$ See Treating Customers Fairly, supra note 160 , at 5.

${ }^{174}$ See id. at 9; Gilad, supra note 157 , at 11 .

${ }^{175}$ See Guide to Management, supra note 170, at 1.

${ }^{176}$ See Treating Customers Fairly, supra note 160, at 11.

${ }^{177}$ Treating Customers Fairly - Culture, FIN. SERVS. AUTH., 2 (July 2007), available at http:/www.fsa.gov.uk/pubs/other/tcf_culture.pdf; see also Treating Customers Fairly, supra note 160 , at 11-12 (referring as well to the goal of effecting a "cultural shift"). 
senior management can convert their good intentions into actual fair outcomes for consumers." 178

At present, there exists limited empirical evidence against which to judge the success (or failure) of the TCF Initiative. Recent qualitative research conducted by Sharon Gilad, however, has examined the TCF Initiative and, specifically, the pre-conditions to its effective implementation. ${ }^{179}$ There are two central findings of this important work. First, external enforcement matters. ${ }^{180}$ Gilad's findings suggest that many financial services firms were initially reluctant to engage with the TCF Initiative because, in their view, these firms already treated their customers fairly. ${ }^{181}$ Indeed, for many firms, engagement involved little more than the collection of data to demonstrate that faimess was, in fact, taken into consideration by their employees. ${ }^{182}$ As Gilad notes, however, this view changed, and more meaningful engagement ensued following a marked increase in the number of enforcement actions stemming from the failure of individual firms to treat customers fairly. ${ }^{183}$ Importantly, the regulator also signaled a firm's failure to meaningfully engage with desired regulatory outcomes-as well as the failure to achieve them-would trigger enforcement action. ${ }^{184}$

The second important finding relates to the role of senior management in spearheading implementation and ongoing engagement. As described above, the TCF Initiative does not seek to compel compliance per se. ${ }^{185}$ Rather, it proceeds on the basis that compliance benefits-i.e., behavioral change leading to improved outcomes for retail clients-will flow from dialogue, process design and implementation, and ultimately, cultural formation. ${ }^{186}$ All of this requires clear signals from senior management that they support (indeed, demand) engagement with TCF Initiative by all

${ }^{178}$ Culture, supra note 177 , at 2.
${ }^{179}$ See Gilad, supra note 157 , at 9.
${ }^{180}$ See id. at 29.
${ }^{181}$ Even when these firms were implicated in various mis-selling claims. See id. at $11-14$.
${ }^{182}$ See id. at 12.
${ }^{183}$ See Gilad, supra note 157 , at $14-16$.
${ }^{184}$ See Treating Customers Fairly, supra note 160 , at 9 ("We will continue to consider enforcement action in circumstances where a firm's systems or actions leave open the potential for significant consumer detriment, or where actual significant detriment has occurred. This is much more likely to be our response where firms continue to deny that TCF has any relevance for them or have failed to take appropriate steps to work out what changes may be required and to start implementing them."); see also id. at 46 (stating that the FSA is "more likely to take enforcement action in cases where a firm has not responded to indications that there are problems, has failed to identify shortcomings and to develop a strategy to deal with them").

${ }^{185}$ See supra notes $174-78$ and accompanying text.

${ }^{186}$ See Gilad, supra note 157 , at 486. 
employees. ${ }^{187}$ To engage with the TCF Initiative purely through a compliance lens, and thereby to give a firm's compliance function primary responsibility for its implementation, would thus undermine its potential efficacy. Gilad's empirical work confirms this perspective: when firms viewed the TCF Initiative as the responsibility of compliance professionals, implementation was measurably slower and less effective. ${ }^{188}$ Notably, then, Gilad's two findings interact: the threat of external enforcement spurs management buy-in, and management buy-in internal enforcement and, ultimately, cultural change.

While empirical data on the impact of the TCF Initiative may be sparse, there are several reasons for (cautious) optimism. First, the TCF Initiative articulates a relatively intelligible and non-arbitragable standard of "other regarding" behavior, thus avoiding two of the principal pitfalls associated with more prescriptive rules. Second, unlike the various codes of conduct and ethics produced by the financial services industry, the credible threat of formal regulatory sanctions in response to failures-not just of compliance but, crucially, of engagement--provides powerful motivation for firms to take the TCF Initiative seriously. Simultaneously, the public disclosure of sanctions imposed for violations of the TCF Initiative reveals valuable information to the retail marketplace about a firm's propensity to treat customers fairly. This could theoretically provide the basis for enhanced market discipline. ${ }^{189}$ If enforcement action, market discipline, and managerial leadership are together able to send a clear, unified signal that engagement will be rewarded - and non-engagement sanctioned-then the TCF Initiative will have made a meaningful contribution to the promotion of a more ethical culture within financial services firms.

${ }^{187}$ Indeed, the FSA has itself stressed that commitment on the part of senior management is crucial to the successful implementation of the TCF Initiative. See Treating Customers Fairly, supra note 160 , at 11 . In a 2006 report outlining the FSA's vision for the TCF Initiative, the role of senior management in the TCF process is referred to 32 times. See generally id at 2-13 (describing the various roles of senior management). Indeed, in stressing the importance of managerial leadership to cultural change within firms, the FSA is at one with leading managerial theories of culture and business practices. See, e.g., EDGAR H. SCHEIN, ORGANIZATIONAL CULTURE AND LEADERSHIP 11 (3d. 2004) (observing that "[i]t can be argued that the only thing of real importance that leaders do is to create and manage culture; that the unique talent of leaders is their ability to understand and work with culture; and that it is an ultimate act of leadership to destroy culture when it is viewed as dysfunctional").

${ }^{188}$ See Gilad, supra note 157, at 20.

${ }^{189}$ Although, in the case of the U.K., oligopolistic competition for many financial products and services - combined with the fact that mis-selling claims have been alleged against a large crosssection of the financial services industry-is likely to have dampened its impact. Ultimately, however, the impact of market discipline in this context is an empirical question which resides beyond the scope of this paper. 
The process-oriented focus of the TCF Initiative thus provides a platform for financial services firms to promote an organizational culture of "other regarding" behavior. To realize this potential, however, the FCA would do well to draw on the insights of cognitive and social psychology canvassed in Part IV of this article. ${ }^{190}$ More specifically, while the TCF Initiative is designed to facilitate dialogue regarding firm practices and the outcomes they achieve for retail clients, the content and framing of these conversations can be important determinants of organizational decisionmaking and behavior. Reframing these conversations to highlight their ethical dimensions could, therefore, yield significant benefits. Thus, for example, the FCA could provide guidance to the effect that meaningful engagement with the TCF Initiative includes reviewing the results of previous enforcement actions (i.e., those against other firms), thereby highlighting the probability and magnitude of potential consequences and providing the foundations of a "lessons learned" review of a firm's own practices. It could similarly mandate that, as part of the vetting process for new products and services, decision-makers confirm that they would recommend purchase of the product or service in question to their grandmother, parent or child (thus enhancing proximity). ${ }^{191}$

The FCA could also mandate that all new financial products and services be vetted and approved by an internal (sub-board level) "ethics" committee-analogous to existing credit committees-headed by senior management and responsible for, inter alia, overseeing delivery of the outcomes identified by the TCF Initiative. The introduction of an ethics committee would offer at least four potential benefits in this context. First, it would signal to the lower rungs of the organization that treating customers fairly (and "other regarding" behavior more generally) was not just a compliance issue, but also an important business issue. ${ }^{192}$ Second, it would provide an opportunity for reflection - for sober second thought about the impact of business decisions on client welfare. ${ }^{193}$ Third, it would establish a clear channel of accountability in terms of compliance with the TCF Initiative, thus eliminating any organizational anonymity which might otherwise decrease the moral intensity of ethical decisions. ${ }^{194}$ Finally, it would provide a direct means of monitoring compliance with ethical norms

\footnotetext{
${ }^{190}$ See supra Part IV.

${ }^{191}$ For these purposes, it would be useful (and perhaps necessary) to assume that the grandmother, parent or child possessed the risk preferences of the "target" client.

${ }^{192}$ See Gilad, supra note 157, at 20.

${ }^{193}$ See id. at $22-23$.

${ }^{194}$ See id. at 24.
} 
by employees. ${ }^{195}$ As examined in greater detail in Part V, many of these same benefits could also flow from the introduction of a board level ethics committee. ${ }^{196}$

Together, these and other mechanisms could potentially enhance moral intensity within financial services firms and put ethical and business considerations on a more equal footing. Moreover, they would allow personal ethical commitments to be foregrounded, and their expression legitimized. As a result, they would enable the personal ethical commitments of employees and managers that are consistent with the TCF Initiative to play a more prominent role in the formation of cultural norms within financial firms. ${ }^{197}$

\section{B. The Extended TCF Initiative}

While further evidence regarding the impact of the TCF Initiative is clearly needed, it is worthwhile exploring the potential merits (and drawbacks) of extending this process-oriented regulatory strategy beyond its current narrow focus on retail customers to encompass transactions involving ostensibly more sophisticated counterparties. ${ }^{198}$ An "Extended" Treating Counterparties Fairly ("Extended TCF") Initiative could apply to transactions involving, for example, swaps and other over-the-counter ("OTC") derivatives, structured finance vehicles, structured investment products, and other more exotic financial instruments. ${ }^{199}$ Like its retail counterpart, the Extended TCF Initiative could contribute to the formation of a more ethical culture within a segment of the financial services industry in which it is widely perceived as lacking. Perhaps most importantly, it could

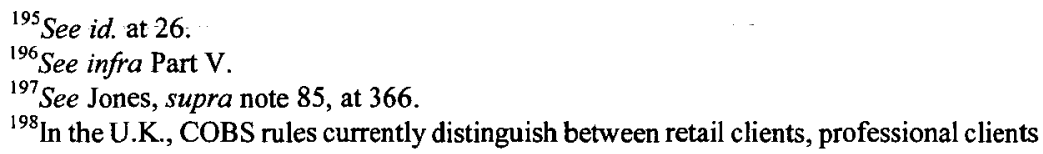
and eligible (i.e., market) counterparties in accordance with, effectively, their ostensible level of financial expertise and sophistication. See COBS, supra note 41, $\S 3.6$. Per se eligible counterparties include, inter alia, investment firms, credit institutions, insurance companies, collective investment schemes, pension funds, governments, and central banks. Id. $\$ 3.6 .2$. In addition, a firm may treat a client as an eligible counterparty if, inter alia, the client is a body corporate (including a limited liability partnership) which, together with its parent company or subsidiaries, has called up share capital of at least $£ 10$ million. $I d$. $\S 3.6 .4$.

${ }^{199}$ We focus on primary markets for two related reasons. First, robust (i.e., transparent, deep, and liquid) secondary markets can be expected to result in more accurate price discovery which, in turn, is itself a tonic against opportunism. Second, in the view of many observers, the most egregious cases of opportunism in recent years - and especially in connection with the GFC-have occurred within the primary markets for these more esoteric, complex and thinly traded instruments. 
serve to deter the design and marketing of financial products and services intended, either in whole or in part, to extract rents from less sophisticated "sophisticated" counterparties. ${ }^{200}$

As with the TCF Initiative, regulators would need to identify the regulatory objectives (or outcomes) an Extended TCF is designed to achieve. These objectives would be tailored to the business context in which they were applied and, therefore, necessarily would be somewhat different from the objectives identified in the retail context. These objectives could include, for example: (1) that the fair treatment of counterparties is embedded in corporate culture; (2) that a counterparty discloses clearly and openly all relevant information about a product which it is marketing; (3) that a counterparty does not attempt to take any steps that could distort the interpretation or weighting of the disclosed information; and (4) that a counterparty does not market products that in its view a reasonably sophisticated market participant would be unable to understand and/or price accurately.

Led by senior management, firms would then be expected to take responsibility for designing bespoke systems, processes, and controls to give effect to these objectives. As with the retail TCF Initiative, the resulting engagement and conversation, backed up by internal enforcement, would facilitate the formation of an ethical culture that treats sophisticated counterparties in accordance with the Extended TCF objectives and legitimizes the expression of consistent personal ethical commitments.

The success of the Extended TCF Initiative, like the TCF Initiative, would ultimately hinge on the extent to which financial services firms (and their employees) meaningfully engage with regulatory outcomes. ${ }^{201}$ Once again, a credible external enforcement threat, in relation to engagement as well as outcomes, is key. ${ }^{202}$ So too is commitment on the part of senior management. ${ }^{203}$ The introduction of an ethics committee to scrutinize transactions and oversee engagement with the Extended TCF Initiative would, for the reasons discussed above, also pay potential dividends. Meanwhile, taking another page from cognitive and social psychology, the FCA could require counterparties to transact "face-to-face" (i.e., either physically or via teleconference) or otherwise attempt to reduce their

${ }^{200}$ See supra notes 46,123 and accompanying text.

${ }^{201}$ See, e.g., Principles-Based Regulation: Focusing on the Outcomes that Matter, FIN. SERVS. AUTH., 2 (Apr. 2007), available at http://www.fsa.gov.uk/pubs/other/principles.pdf (noting that "[f]irms' behaviour and positive engagement with the regulatory outcomes will also be a factor that is taken into account in [the FCA's] regulatory action towards that firm").

${ }^{202}$ See Treating Customers Fairly, supra note 160, at 9.

${ }^{203} \mathrm{Id}$. at 11 . 
physical, psychological, or social proximity. While such proposals might seem too costly, or unrealistic, or remnants of a bygone era, there is no denying the fact-as evidenced by the heightened emotional response to the footbridge problem ${ }^{204}$ - that it is often more difficult to take advantage of your counterparty once you have shaken their hand.

There are, however, a number of reasons to suggest that the Extended TCF Initiative might not be as effective as its retail counterpart. Perhaps most importantly, unlike the retail marketplace, there is arguably no underlying societal norm that sophisticated market counterparties should be treated fairly. Indeed, there is a strong countervailing norm of caveat emptor within many wholesale markets. ${ }^{205}$ More specifically, where sophisticated parties fail to fully understand the nature or extent of the risks they contract to assume, the general view is thus that they have no one to blame but themselves and should, accordingly, bear the consequences of their ignorance, incompetence, and/or greed. Viewed from this perspective, extending regulatory strategies such as the TCF Initiative to ostensibly more sophisticated counterparties amounts to unwarranted paternalism. This, in turn, is likely to dilute the impact of any reputational (i.e., market-based) sanctions for firms which are deemed to have treated their counterparties unfairly. ${ }^{206}$ Ultimately, however, such likely counterarguments arguably miss the point. As Milton Friedman observed, efficiency demands that contractual exchange is both voluntary and, importantly, informed ${ }^{207}$ The Extended TCF Initiative must ultimately be judged on the basis of whether it engenders the formation of cultural norms which would promote such informed (and therefore more efficient) contracting.

\section{WHO IS MY NEIGHBOR? CAR VING OUT A ROLE FOR A MORE ETHICAL CULTURE IN SYSTEMIC RISK REGULATION}

The GFC has driven home the reality that financial services firms frequently do not possess the incentives to take systemic risk seriously. ${ }^{208}$

\footnotetext{
${ }^{204}$ See Valdesolo \& DeSteno, supra note 95, at 476; Greene et al., supra note 99, at 2106; Gold et al., supra note 95.

${ }^{205}$ See Clive Adamson, Dir. of Supervision, Conduct Bus. Unit, Speech on the FCA at the Bloomberg Conference: Conduct Supervision and the Move Towards the FCA (noting that the FCA "will generally continue to rely on the caveat emptor principle and not seek to introduce concepts of detriment and redress that we use in retail markets to wholesale markets").

${ }^{206}$ In response to the loss of reputational discipline, the regulator could deploy other enforcement strategies. See infra notes 211-12 (discussing the "fit and proper purpose regime").

${ }^{207}$ MILTON FRIEDMAN, CAPITALISM AND FREEDOM 13 (1962).

${ }^{208}$ See, e.g., Jaime Caruana, Bank for Int'l Settlements, Systemic Risk: How to Deal with It?, 1 (Feb. 12, 2010) available at http://www.bis.org/publ/othp08.htm (noting that "[s]ystemic risk was
} 
While these firms, their shareholders, and their employees capture the benefits derived from their socially excessive risk-taking, they bear only a portion of the attendant costs. Indeed, of all the issues to emerge from this crisis, the diversion of public resources to private firms in order to prevent the collapse of the financial system remains the most acute and controversial. The salient question thus becomes: can process-oriented regulation help constrain socially excessive risk-taking within financial services firms? Put differently: does the TCF Initiative's process-oriented approach provide a template for what we might for argument's sake call a "Taking Externalities Seriously" (or "TES") Initiative? ${ }^{209}$

A TES Initiative could identify and seek to achieve the following regulatory objectives: (1) ensure that the identification and avoidance of socially excessive risk-taking is embedded in corporate culture; (2) identify and continually monitor any risks generated by the firm's activities which manifest the potential to create or exacerbate systemic risk; (3) better understand a firm's exposure to systemic risks; and (4) determine how best to minimize these risks on an ongoing basis. These objectives would, inter alia, engage firms in the important and difficult task of developing better metrics of systemic risk-something which represents an ongoing challenge for regulators. ${ }^{210}$ Importantly, where firm-level processes yielded significant improvements in terms of the measurement or management of systemic risk, these improvements could be disseminated by regulators in the form of industry guidance thereby helping to overcome the inherent incentive problems arising from the fact that financial stability is a public good.

Like the TCF Initiative, the TES Initiative would seek to make socially excessive risk-taking a business and cultural issue for firms, with compliance measured against both the delivery of desired regulatory outcomes and ongoing engagement. Through internal engagement and dialogue arising from the development and implementation of processes,

underestimated across the board before this crisis").

${ }^{209}$ For the present purposes, we bracket questions about the types of financial institutions to which the TES Initiative should apply. One argument is that the TES Initiative should apply only to systemically important firms, as it is only those institutions whose failure threatens to generate the type of negative externalities unleashed by the GFC. There are, however, several arguments in favor of more general application. First, a more targeted application does not take account of the potential contagion effects of non-systemically important firms which engage in socially excessive risk-taking in herds. Second, employees from firms not subject to the TES Initiative could relocate to firms which were subject to it (and vice versa). Insofar as these employees were unfamiliar with the TES Initiative, this might be expected to undermine attempts at norm formation within systemically important institutions.

${ }^{210}$ See Dimitrios Bisias et al., A Survey of Systemic Risk Analytics 46 (Office of Fin. Research, Working Paper No. 0001, Jan. 5, 2012), available at http://www.treasury.gov/ initiatives/wsr/ofr/Documents/OFRwp0001_BisiasFloodLoValavanis_ASurveyOfSystemicRiskAnal ytics.pdf. 
systems, and controls-backed by managerial commitment-the TES Initiative would aim to foster the generation of a cultural norm within firms that promotes awareness amongst all employees that their conduct has social consequences. Awareness, of course, is not the same thing as understanding. Individual actors, no matter how intelligent, are incapable of processing the full systemic implications of their activities. Yet awareness that their actions may have systemic implications may generate some individual restraint, as well as encourage engagement with the processes, systems and controls designed to manage these risks.

In effect, the processes, systems, controls, and norms generated by an effective TES Initiative would result in firms internalizing some of the social costs of their activities. On paper, therefore, the potential benefits of the TES Initiative are compelling. But are they achievable? As a preliminary matter, the conceptual problems associated with the design and implementation of the TES Initiative would be significantly greater than either the TCF Initiative or Extended TCF Initiative. While "fairness" is in many respects an amorphous concept, it can readily be given more precise content in the context of the bilateral customer or counterparty relationships. ${ }^{211}$ Socially excessive risk-taking, in contrast, is extremely difficult to define, let alone identify before the moment it crystallizes as a negative externality. These conceptual problems would undoubtedly render it more difficult for regulators to provide meaningful firm-specific and industry guidance. They would also make enforcement action stemming from the failure to achieve desired regulatory outcomes inherently more problematic. ${ }^{212}$ These enforcement problems would be compounded by the likely impotence of market-based (i.e., reputational) sanctions in response to socially excessive risk-taking. ${ }^{213}$

Perhaps the most compelling response to these very legitimate concerns is that, as described above, process-oriented regulation is designed to promote engagement with desired regulatory outcomes and, through engagement, to promote cultural norms that deter socially undesirable

${ }^{211}$ As the six outcomes identified by the TCF Initiative attest. See Treating Customers Fairly, supra note 160 , at 3.

${ }_{212}$ Any uncertainty regarding the required regulatory standard could of course lead to legal challenges. Moreover, in extremis - i.e., where the materialization of a risk will wipe out the assets of the firm - we would expect the threat of ex post enforcement for failing to achieve desired regulatory outcomes to have a negligible impact on ex ante incentives to take the risk (especially where there was no recourse to the assets of the decision-makers). This is because in states of the world where the risk materializes, the marginal costs of enforcement action would be zero.

${ }^{213}$ See, e.g., Armour et al,, supra note 135, at 3 (finding that news of enforcement actions in connection with wrongdoing which harmed third parties had a weakly positive effect on a firm's share price). 
behavior. ${ }^{214}$ In the aftermath of the GFC, it cannot be denied that there is such a thing as socially excessive risk-taking or that the externalities thereby generated are very real. Nevertheless, it is inevitable that when dealing with something as complex as socially excessive risk-taking, different firms (and even regulators) will adopt divergent perspectives respecting, inter alia, whether and to what extent various activities generate systemic risk and how best to address it.

What process-oriented regulatory strategies such as the proposed TES Initiative attempt to do is stimulate meaningful and ongoing dialogue within firms about these important questions. ${ }^{215}$ It then provides firms with the flexibility to design and implement firm-specific processes which reflect the results of this dialogic process. ${ }^{216}$ Put simply, in a domain where there are few right answers, the objective of the TES Initiative would be to engender a culture in which firms continually question the impact of their activities on others. ${ }^{27}$ Viewed in this light, any conceptual indeterminacy in terms of desired regulatory outcomes would be unlikely to pose a significant obstacle to such cultural formation.

Furthermore, although effective enforcement action would undoubtedly be more problematic in connection with the TES (relative to the TCF) Initiative, it bears emphasizing that enforcement action need not be based solely on the failure to achieve outcomes, but also on the basis of the firm's engagement with, and the level of commitment by senior management to, achieving the regulatory outcomes. ${ }^{218}$ Moreover, regulators could also deploy indirect sanctions. Utilizing a holistic ${ }^{219}$ approved persons regime, ${ }^{220}$

${ }^{214}$ See supra notes $159-60,165$ and accompanying text.

${ }^{215}$ See supra notes 176,186 and accompanying text.

${ }^{216}$ See supra note 159 and accompanying text.

${ }^{217}$ See supra note 161 and accompanying text.

${ }^{218}$ See supra notes 148,187 and accompanying text.

${ }^{219}$ Under such a regime, when presented with an approval request for a controlled function (see note below), the FCA would consider the fitness of the applicant relative to the fitness and competences of the board and management as a whole. The FCA has indicated that in considering the competence of any applicant for a controlled function the competence of other approved persons for that function will be relevant to ensure the institution has appropriate competences as a whole. FSA, CONSUltation Paper 10/3, EFFective Corporate Governance: Significant INFLUENCE CONTROLLED FUNCTIONS AND THE WALKER REVIEW $\$ 4.28$ (2010).

${ }^{220}$ Any person performing a "controlled function" of an authorized person must be approved by the FCA. Financial Services and Markets Act 2000, 2000, c. 8, § 59(1) (U.K.). Such person must be "a fit and proper person." Id. $\$ 61(1)$. Controlled functions currently consist of governing functions (for example, director or non-executive director function), significant management functions, systems and control functions and required functions. FCA, FCA HANDBOOK CHAPTER 10: APPROVED PERSONS $\S 10.4$ (2013), available at $\mathrm{http} / / /$ info/FS/html/handbook/FCA/SUP/6. The FCA has recently proposed broadening the range of control functions, a change that, although currently delayed, will enhance the FCA's control over the 
for example, a regulator could deny approval if the candidate did not have the skills, qualities, or commitment necessary to counteract a firm's ineffective engagement with the TES Initiative. Alternatively, regulators could designate a candidate as "board-level champion" for the TES Initiative. ${ }^{221}$

\section{Treating Banks Differently: Preconditions to the EMERGENCE OF BINDING CULTURAL AND ETHICAL CONSTRAINTS}

The objective underlying the TCF, Extended TCF, and TES Initiatives is to foster a more ethical culture within financial services firms. Yet, as the GFC has illustrated, private incentives will at times come into conflict with both pre-existing personal ethical commitments as well as the pursuit of public regulatory objectives. ${ }^{222}$ It follows that, in order for a meaningful ethical culture to form and flourish through process-oriented regulation, we must first address these countervailing incentives. This section explores some of the ways this might be achieved.

The U.K.'s experience with the TCF Initiative drives home the importance of leadership and commitment on the part of senior management as a necessary precondition to any shift toward a more ethical culture within financial services firms. In this regard, if any stated commitment on the part of senior managers is not backed up by observable action to implement the TCF, Extended TCF, and TES Initiatives (and then monitor and enforce compliance), it is highly unlikely that the desired "cultural shift" will take place. ${ }^{223}$ However, whereas employees will observe and easily interpret mixed managerial signals, regulators may struggle to differentiate between managerial (unequivocal) word and (equivocal) action. Managers may, therefore, be able to creatively comply through ostensible engagement that ultimately has limited impact on the ground. Clearly then, managerial incentives are central to the success of the initiatives.

There are two key drivers of the incentive structures of senior managers. The first driver is personal compensation arrangements, where those arrangements are linked directly or indirectly to financial targets. The second is managers' relationship with shareholders and, ultimately,

personnel and board structure of financial institutions. FSA, IMPLEMENTATION OF THE NEW SIGNIFICANT INFLUENCE CONTROLLED FUNCTIONS (SIFS) DEFERRED (2011).

${ }^{221}$ See Treating Customers Fairly, supra note 164, at 3.3 (noting that some firms have designated a board-level champion for the TCF Initiative).

${ }^{222}$ See supra notes 23-28 and accompanying text.

${ }^{223}$ See supra note 187 and accompanying text. 
shareholder value. Shareholders in financial institutions, as in other firms, possess strong incentives to encourage managers to focus on value creation. ${ }^{224}$ Within systemically important financial institutions, however, these same incentives also drive shareholders to encourage managers to take socially excessive risks. ${ }^{225}$ As has been argued elsewhere, where creditors do not discipline institutions that benefit from the TBTF subsidy and where the state does not demand full payment for its implicit guarantee, ${ }^{226}$ shareholders, including long-term shareholders, have powerful incentives to encourage managers to increase the volatility and, therefore, riskiness of the institution's asset profile. ${ }^{227}$ That is, encouraging managers to "bet the bank" is rational for shareholders who think only about the value of their own portfolio. Accordingly, to increase the probability that measures such as the TCF, Extended TCF, and TES Initiatives will succeed, managers need to be given room to resist shareholder pressure to focus only on shareholder value.

What, then, are the remuneration and other governance tools available to create the decision-making space necessary to enable a more ethical culture--institutionalized through measures such as the TCF, Extended TCF, and TES Initiatives - to flourish? Below we canvass a range of possible strategies. ${ }^{228}$ Some of these strategies-remuneration and corporate objective regulation, for example - may be viewed as pre-requisites. ${ }^{229}$ Others, meanwhile, may be more appropriately viewed as facilitative but, ultimately, optional. Moreover, certain of these optional governance strategies may be viewed as, at least in part, substitutable; the absence of one may be counterbalanced by the presence of another. Accordingly, whether any particular jurisdiction creates governance structures that provide fertile soil for our proposals must be assessed holistically. Such comparative jurisdictional assessments are beyond the scope of this article.

\section{A. Composition Reforms: A Board Level Ethics Committee}

An important question raised by the GFC is whether weaknesses in the structure and composition of the boards of directors of financial

\footnotetext{
${ }^{224}$ See supra note 16 and accompanying text.

${ }^{225}$ See supra notes 141-45 and accompanying text.

${ }^{226}$ See JOSEPH NOSS \& RHIANNON SOWERBUTT, BANK OF ENGLAND, FINANCIAL STABILITY PAPER NO. 15, THE IMPLICIT SUBSIDY OF BANK (2012), available at http://www.bankofengland.co.uk/publications/Documents/fsr/fs_paper15.pdf.

${ }^{227}$ See Christopher M. Bruner, Corporate Governance Reform in a Time of Crisis, $36 \mathrm{~J}$. CORP. L. 309, 312 (2011).

${ }^{228}$ See infra Parts VI.B-E.

${ }^{229}$ See infra Parts VI.B-C.
} 
institutions were a proximate cause of their failure. The focus to date has been on the competences of independent non-executive directors-i.e., whether they were sufficiently knowledgeable about their firms and the financial services industry -and the role of the board in effectively managing risk. ${ }^{230}$ The primary regulatory response in this regard has been to require or recommend that financial institutions (i.e., banks and other "credit institutions") form board-level risk committees under the control of independent directors. ${ }^{231}$

To date, ethics and culture have not been featured in this board composition debate. In the U.K., for example, the important Walker Review on the Corporate Governance in UK Banks and other Financial Entities did not address ethics or envision a specific role for boards with regard to firm ethical culture. ${ }^{232}$ Nevertheless, many U.K. companies, including financial institutions, do have (and had prior to the crisis) board committees whose remit it is to address firm ethics. ${ }^{233}$ It is important to keep in mind, however, the limits to board composition reforms in general. In the case of the major bank failures during the crisis, for example, it is unlikely that such reforms would have prevented the bank failures in question or, indeed, have altered the board composition of many of those failed banks. ${ }^{234}$

Nevertheless, the role of a board-level ethics committee within financial institutions is worth canvassing in the post-crisis board composition

${ }^{230}$ See, e.g., DAVID WALKER, A REVIEW OF CORPORATE GOVERNANCE IN U.K. BANKS AND OTHER FINANCIAL INDUSTRY ENTITIES: FINAL RECOMMENDATIONS 14, 19 (2009), available at http://webarchive.nationalarchives.gov.uk/+/http:/www.hm-treasury.gov.uk/d/walker_review 261109.pdf (recommending that non-executive directors "have the knowledge and understanding of the business to enable them to contribute effectively").

${ }^{231}$ See, e.g., BCBS, PRINCIPLES FOR ENHANCING CORPORATE GOVERNANCE $§ 52(2010)$, available at http://www.bis.org/publ/bcbs1 76.pdf (suggesting a board-level risk committee for banks which-would-be-"responsible for advising the board on the bank's overall current and future risk tolerance/ appetite and strategy, and for overseeing senior management's implementation of that strategy"); FCA, SENIOR MANAGEMENT ARRANGEMENTS, SYSTEMS AND CONTROLS $§ 21.1 .5$ (2013) ("The FCA [suggests] that . . . firms should consider establishing a governing body risk committee to provide focused support and advice on risk governance.").

${ }^{232}$ See generally WALKER, supra note 230, at 14-18 (focusing on how the board will provide business awareness).

${ }^{233}$ See DAVID WALKER, A REVIEW OF CORPORATE GOVERNANCE IN U.K. BANKS AND OTHER FINANCIAL INDUSTRY ENTITIES: CONSULTATION DOCUMENT 128 (2009), available at

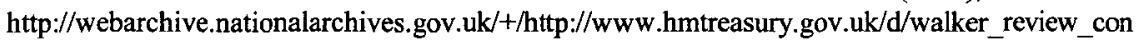
sultation_160709.pdf (reporting a review by Deloitte indicating that $33 \%$ of Banks-as compared to $40 \%$ of all companies-as of 2008 had a committee that dealt with issues of "CSR/Environment/Ethics/Health \& Safety"). The remit of such committees is, of course, considerably wider than the issues considered in this paper.

${ }^{234} \mathrm{See}$, e.g., THE ROYAL BANK OF SCOTLAND, ANNUAL REPORT AND ACCOUNTS 2 (2006), available at http://www.investors.rbs.com/download/report/RBSplc_Accounts_2006.pdf (listing the bank's pre-crisis board of directors). 
debate. An ethics committee could form a key component of an attempt to generate an "other regarding" ethical culture within financial institutions. As we have seen, the process-orientated strategies place significant weight on the role played by senior management. An ethics committee, on which executive and non-executive directors sit and to which senior management reports, would be vital in: (1) signaling to management and all employees the importance of the formation of an ethical culture; and (2) establishing effective monitoring, reporting, and other mechanisms to oversee its design and implementation.

Working together with senior management, an ethics committee would take the lead in establishing and revising a firm's cultural/ethical objectives consistent with applicable regulatory objectives, including those identified by the TCF, Extended TCF, and TES Initiatives. ${ }^{235}$ More specifically, an ethics committee would be responsible for setting the firmspecific ethical outcomes and then monitoring the processes developed by management and employees, and benchmarking their effects in practice and over time. ${ }^{236}$ An ethics committee could also be responsible for putting in place and monitoring the effectiveness of ethical disciplinary procedures within the firm and for overseeing the management information systems that gather information about engagement and compliance with the processes and procedures designed to engender a more ethical culture.

Because the generation of an ethical culture is both an operational and monitoring issue (the goal being to infuse ethical considerations into institutional activities), such a committee would consist of both executive and non-executive directors. However, as its key function would be to hold management accountable for their leadership and engagement with the Initiatives, the ethics committee would be majority controlled by the nonexecutive directors.

\section{B. Remuneration}

The view is now widespread that one of the primary drivers of socially excessive risk-taking within financial institutions prior to the GFC was the remuneration arrangements of both executive directors and lower level bankers and traders. These arrangements incentivized decision-making that

${ }^{235}$ See supra note 160 and accompanying text.

${ }^{236} \mathrm{As}$ a board-level committee it could not, however, be closely involved in the design and implementation of the processes necessary to achieve these objectives. As discussed above, of central importance to process-oriented regulation is harnessing the firm's ground-level knowledge and expertise, and making engagement with regulatory objectives a central part of a firm's ethos. 
focused on short-term financial gains (often unrealized in cash terms). Indeed, in many instances, financial institutions appear to have remunerated managers and other employees by taking account of the short-term upside of transactions, but not the potential long-term downside. ${ }^{237}$ In the wake of the crisis, domestic and transnational regulatory responses ${ }^{238}$ have thus focused on ensuring that: (1) pay more accurately reflects both short-term and longerterm risks; (2) there are limits on the performance-based component of pay; (3) any performance-based component has a limited cash component; and (4) a substantial portion of performance-based pay is deferred over a significant period of time (i.e., over three to five years). ${ }^{239}$

Even where remuneration arrangements are linked to the long-term value of the firm, however, these arrangements may still generate incentives to cut ethical corners. To the extent that firms profit from the exploitation of asymmetries of information and expertise in relation to highly complex products such actions impose costs on their less informed and/or inexpert counterparties, thereby generating quasi-rents. In relation to socially excessive risk-taking, meanwhile, the long-term outlook of the financial institution may support an approach to risk that, from society's perspective, is clearly undesirable. Specifically, if the primary objective of financial

${ }^{237}$ See generally Lucian A. Bebchuk \& Holger Spamann, Regulating Bankers Pay, 98 GEO. L. J. 247(2010) (examining and suggesting alternatives to compensation structures that focused on short-term results and encouraged excessive risk-taking); see also Coffee, supra note 30 , at 1047 ("Because a rapid shift towards incentive-based compensation at financial institutions focused senior management on short-term results, longer-term risks were ignored or excessively discounted.").

${ }^{238}$ See, e.g., COMMISSION OF THE EUROPEAN COMMUNITIES, COMMISSION RECOMMENDATION ON REMUNERATION POLICIES IN THE FINANCIAL SERVICES SECTOR (2009), available at http://ec.europa.eu/internal_market/company/docs/directors-remun/financialsector 290409_en.pdf ("Remuneration policy should be in line with the business strategy, objectives, values and long-term interest of the financial undertaking . . . "); COMMITTEE OF EUROPEAN BANKING SUPERVISORS, GUIDELINES ON REMUNERATION Policies aNd Practices (2010), available at $\mathrm{http} / / \mathrm{www}$.eba.europa.eu/cebs/media/Publications/Standards\%20and\%20Guidelines/ 2010/Remuneration/Guidelines.pdf; FDIC, FIL-7-2011 (It is . . appropriate to specify clear principles on sound remuneration to ensure that the structure of remuneration does not encourage excessive risk-taking by individuals or moral hazard and is aligned with the risk appetite, values and long-term interests of the credit institution or investment firm."); INTERAGENCY NOTICE OF PROPOSED RULEMAKING: INCENTIVE- BASED COMPENSATION ARRANGEMENTS (2011), available at http://www.fdic.gov/news/news/financia1/2011/fill1007.pdf ("This [Notice on Proposed Rulemaking] seeks to strengthen the incentive compensation practices at covered institutions by better aligning employee rewards with longer-term institutional objectives."); SENIOR MANAGEMENT ARRANGEMENTS, supra note 235, \$ 19A ("A firm must ensure that its remuneration policy is in line with the business strategy, objectives, values and long term interest of the firm.").

${ }^{239}$ See SENIOR MANAGEMENT ARRANGEMENTS, supra note $231, \S 19 \mathrm{~A} .3 .49$. Note that these standards are applied on a "firm-wide" basis and are therefore applicable to executive directors as well as bankers and traders. 
institutions, as organizations, is to generate shareholder value (which we discuss further below) then rational managers acting in the interests of their shareholders will exploit the implicit and uncosted state guarantee. ${ }^{240}$

As a result, maximizing shareholder value will support an approach that promotes excessive risk-taking, ultimately transferring value from the state to shareholders. If the risks pay off shareholders win; if they do not, society loses. ${ }^{241}$ Requiring employees to maximize a firm's value within a three to five year time frame (as the new remuneration rules and guidelines effectively require) will thus not necessarily place a break on socially excessive risk-taking.

In theory, claw-back provisions hold out greater potential to alter the incentives of senior managers and other employees. Correctly drafted, clawbacks can ensure that the costs generated by socially excessive risks are borne not just by society, but also by the individuals who actually took them. The devil of such claw-backs, however, is in the detail. Do they apply to paid or merely deferred remuneration? If the former, how far is the lookback period in relation to which the claw-back can be applied? What is the extent of prior earnings which must be re-paid? Claw-backs of the variety set forth in the FCA's Remuneration Code ${ }^{242}$ which apply only to unvested deferred remuneration, incentivize rational managers and employees to discount only the deferred benefit of the socially excessive risk-taking by the probability that the risks will be realized within the vesting timeframe..$^{243}$ In these behavioral calculations, we would expect the senior managers or employees to also take into account the benefits of any increase in fixed (and non-recoverable) salary, as well as job security, arising from risking-taking aligned with broader institutional incentives. Compounding matters, financial institutions may attempt to realign incentives by simply increasing fixed pay.

The Dodd-Frank Act, in contrast, authorizes the FDIC to impose clawbacks on senior executives who are "substantially responsible" for bank failure. $^{244}$ On one level, the FDIC claw-backs are broader than those

${ }^{240}$ See Coffee, supra note 30, at 1053; see generally Noss \& Sowerbutts, supra note 230 (examining public costs of the implicit government guarantee).

${ }^{241}$ See Coffee, supra note 30, at 1048.

${ }^{242}$ See SENIOR MANAGEMENT ARRANGEMENTS, supra note 231 , $\$ 19$ A.3.52 (providing for the reduction "unvested deferred" remuneration in the event of "employee misbehaviour", or where a business unit suffers a "material downturn in [firm] financial performance" or "a material failure of risk management").

${ }^{243}$ See id $\$ 19 \mathrm{~A} .3 .52-53$.

${ }^{244}$ Dodd-Frank Act, Pub. L. No. 111-203, §203(s), 124 Stat. 1376, 1514 (2010). In the event of bank bailout, the FDIC would not be appointed as receiver. There remain doubts about the legality of this provision. See Dorothy Shapiro, Federalizing Fiduciary Duty: The Altered Scope of 
provided for under FCA rules insofar as they apply to all compensation. ${ }^{245}$ On another level, however, they are narrower in that they (1) focus on personal rather than collective (i.e., business unit) responsibility and (2) only apply when a bank is in FDIC receivership..$^{246}$ Furthermore, the FDIC rules will only apply to compensation earned within one to two years of the appointment of the FDIC as receiver. ${ }^{247}$ A rational manager would therefore discount the benefit of risky behavior against the probability that such risks will result in receivership in a one to two year period (as well as the probability that the FDIC will be able to establish "substantial responsibility"). As the crisis has demonstrated, however, holding individual managers accountable is very difficult. Moreover, for systemically important banks, the probability of even entering an insolvency proceeding is low. As such, the probability of claw-back under these rules is also low.

The personal and institutional incentives of senior managers and other employees subject to the reformed remuneration rules manifest the potential to crowd out a process-oriented approach to cultural and ethical norm formation. Within such an environment, there is a risk that measures such as the TCF, Extended TCF, and TES Initiatives would be reduced to ethical window dressing. At the same time, it has now become relatively commonplace for companies to include non-financial targets such as employee satisfaction, health and safety, and environmental measures alongside financial measures in executive remuneration arrangements. ${ }^{248}$ Indeed, the U.K. FCA's Remuneration Code states that "[n]on-financial performance metrics should form a significant part of the performance assessment process .... [these non-financial risk metrics include] risk management and compliance with the regulatory system . . . ."249 Indeed, some financial institutions have voluntarily gone further than this. Morgan Stanley, for example, has recently altered the provisions in its remuneration arrangements with senior managers to enable claw-backs where, inter alia, there are violations of articulated ethical standards. ${ }^{250}$ Such non-financial

Officer Fiduciary Duty Following Orderly Liquidation under Dodd-Frank, 17 STAN. J.L. BuS. \& FIN. 223, 226.

${ }^{245}$ See Dodd-Frank Act $\$ 203(\mathrm{~s})$.

${ }^{246}$ See id.

${ }^{247} \mathrm{Id}$.

${ }^{248}$ See PRICEWATERHOUSECOOPERS, EXECUTIVE COMPENSATION: REVIEW OF THE YEAR 2009 70-71 (2010), available at http:/www.pwc.co.uk/assets/pdf/executive-compensation-reviewof-the-year-2009-pwc.pdf.

${ }^{249}$ SENIOR MANAGEMENT ARRANGEMENTS, supra note 231 , $\$ 19$ A.3.37.

${ }^{250}$ See Morgan Stanley, Proxy Statement (Schedule 14A), 28-29 (Apr. 5, 2012), available at http://www.sec.gov/Archives/edgar/data/895421/000119312512151028/d303252ddef14a.htm. See generally Sharlene Goff \& Daniel Schäfer, Banks Ready to Claw Back More Bonuses, FIN. TIMES (London), Aug. 27, 2012, available at http://ft.com (search title) (discussing how "recent scandals 
targets could be extended to explicitly incorporate the level of engagement, implementation, and compliance with the TCF, Extended TCF, and TES Initiatives. Building on the role of ethics committees noted above, and the existing role of risk committees vis-à-vis remuneration, ${ }^{251}$ the ethics committee could take responsibility for setting such non-financial remuneration targets. Furthermore, by connecting remuneration to the performance of a collective part of the financial institution-a product group, business unit, or division, for example-remuneration could drive peer group monitoring, thereby strengthening two of the three pillars of norm formation: the observation and dissemination of information about the violation of cultural norms.

\section{Corporate Law: The Objective of Bank Activity}

There is a longstanding debate regarding in whose interests a company should be run-i.e., whose interests should directors consider when they make decisions. ${ }^{252}$ Many argue that directors should be required to take into account the interests of all corporate stakeholders when they act without any legal direction to prioritize one constituency over another. ${ }^{253}$ This approach is referred to by commentators as a "pluralistic" or "multiple-interest" model of the corporation. ${ }^{254}$

Several justifications have been given for this approach. For example, some commentators, observing that the corporate form is a "gift" from the state and that corporations exert enormous influence over all our lives, have argued that with great power comes quasi-public responsibility to consider the interests of all stakeholders. ${ }^{255}$ Economic justifications, meanwhile, focus on the incentives for firm-specific human capital investments by employees which are generated by knowing that their interests count as much as anyone else's. ${ }^{256}$ Whether or not one is persuaded by such arguments more

in the sector ... and mis-selling of financial products to anti-money laundering failures and sanctions breaches - are prompting big banks to increasingly strip staff of awards they received for past performances that no longer look favourable").

${ }^{251}$ See, e.g., SENIOR MANAGEMENT ARRANGEMENTS, supra note $231, \S 21.1 .5(\mathrm{f})$ (suggesting that "the firm's governing body ... should consider establishing a governing body risk committee to provide focused support and advice on risk governance").

${ }^{252}$ DaVID KERSHAW, COMPANY LAW IN CONTEXT: TEXT AND MATERLALS 357 (2d ed. 2012).

${ }^{253}$ See generally id. at 357-78 (discussing commentators' perspectives regarding shareholder and stakeholder interests as comprising a company's interests).

${ }^{254}$ See id. at 370.

${ }^{255}$ See E. Merrick Dodd, Jr., For Whom are Corporate Managers Trustees?, 45 HARV. L. REV. 1145, 1149 (1932).

${ }^{256}$ See Margaret M. Blair \& Lynn A. Stout, A Team Production Theory of Corporate Law, 85 VA. L. REV. 247, 272 (1999). 
generally-given the stark consequences of the GFC and the necessity for publicly funded bail-outs - the case for a multiple-interest model in relation to financial institutions is compelling. At the very least, there is a powerful justification in relation to systemically important institutions for a model that gives equal weighting to the interests of customers (depositors, counterparties, etc.), shareholders, and broader society.

A form of the multiple-interest model is essential for creating the conditions in which the TCF, Extended TCF, and TES Initiatives can facilitate the formation of a more ethical culture. All actors, from the board down to the individual trader, need to know that when there is a conflict between regulatory objectives and the pursuit of value that it is lawful, legitimate, and expected that they will prioritize fair treatment or the avoidance of potential externalities. Managerial leadership and commitment-an essential pre-requisite to the formation and enforcement of cultural norms - will manifestly be undermined if the law's core statement of the directors' obligations fails to take account of the "other regarding" obligations that are foundational to achieving this objective. Furthermore, the imposition of a legal obligation to make decisions on the basis of an "other regarding" standard may assist managers in managing, and at times resisting, shareholder pressure to take excessive risks.

In most jurisdictions, this pre-requisite to the formation of a more ethical culture is unproblematic because all corporations are subject to a multiple interest model of corporate purpose. This is the case, for example, for firms incorporated in New York, Germany, or Austria. ${ }^{257}$ The U.K., however, is one jurisdiction where this is not the case. This is because, in the U.K., directors' duties require them to act in a way in which that they consider will promote shareholder interests. ${ }^{258}$ Indeed, it is worthwhile noting in this regard that the Walker Review rejected the suggestion that the existing duty should be amended to reflect the fact that banks are different. ${ }^{259}$ Encouragingly, however, recent remarks by a former CEO of the FSA on the

${ }^{257}$ See N.Y. BUS. CORP. LAW § 717(b) (2010); AUS. STOCK CORP. LAW § 70(1) (2013). In Germany, while the Stock Corporation Act is silent on the question of corporate objectives, it is widely accepted that the management board should act in the interests of shareholders, employees and society at large. Wolfgan Hefermehl \& Gerald Spindler, in 3 Münchener Kommentar zum Aktiengesetz 58, \$ 76/53 (Bruno Kropff \& Johannes Semler eds., Beck, 2d ed. 2004).

${ }^{258}$ Companies Act, 2006, c. $46, \S 172$. Whilst the provision requires that directors have regard to other stakeholders, the provision is clear that the decision itself must prioritize the interests of the shareholders. See id.

${ }^{259}$ See WALKER REVIEW, supra note 230, at 138. 
subject of banking culture suggest that U.K. regulators may be open to the idea of revisiting this issue ${ }^{260}$

\section{Corporate Law: Shareholder Rights}

One needs to be wary of overstating the importance of the corporate purpose debate. Through an instrumental lens, even if given discretion to act in the interests of multiple constituencies, it seems probable that the constituency to whom directors and managers will be compelled to answer will be the constituency whose interests they prioritize in the case of conflict between shareholder value and other stakeholder interests. That is, the background structure of shareholder rights will continue to influence decision-making within financial institutions. However, whilst in all jurisdictions shareholders have the power to appoint, remove, and (not) reappoint directors, they are not equal when it comes to the nature and extent of shareholder rights. ${ }^{261}$ As a result, the effects those rights have on senior management and firm decision-making and behavior may also differ.

In the U.K., for example, shareholders have very powerful rights. They have the non-waivable right to remove directors without cause by passing a simple majority resolution, ${ }^{262}$ along with the right to call a meeting at any time when five percent of the shareholder body instructs the board to call a meeting. ${ }^{263}$ By way of contrast, in the U.S., although the rules vary from state to state, most financial institutions may select jurisdictions which permit weaker removal rights. A firm incorporated in Delaware, for example, can elect to have a classified board where the directors have three year terms and can only be removed with cause ${ }^{264}$ during this term. ${ }^{265}$

${ }^{260}$ Hector Sants, Chief Executive, FSA, Speech to the Chartered Inst. of Secs.\& Invs. Conference: Do Regulators Have a Role to Play in Judging Culture and Ethics? (June 17, 2010) (transcript available at http://www.fsa.gov.uk/library/communication/speeches/2010/0617 hs.shtml) (stating that the corporate purpose objective must include "a stronger and more explicit obligation to wider society").

${ }^{261}$ Compare DEL. CODE. ANN. tit. 8, \$141(k) (2010) ("Any director or the entire board of directors may be removed, with or without cause, by the holders of a majority of the shares then entitled to vote at an election of directors, except as [provided under subsections (1) or (2)]."), with Companies Act, 2006, c. 46, $\$ 168$ (1) ("A company may by ordinary resolution at a meeting remove a director before the expiration of his period of office, notwithstanding anything in any agreement between it and him.").

${ }^{262}$ See Companies Act, 2006, c. $46, \S 168$.

${ }^{263}$ See id. $\$ \$ 303-05$.

${ }^{264}$ See Campbell v. Loews, Inc., 134 A.2d 852, 857 (Del. Ch. 1957) (The "cause" threshold is a high one in effect requiring some form of breach of duty or illegality).

${ }^{265}$ See tit. 8, $\$ 141(\mathrm{k})$. Note that the "with cause" removal right is itself a default rule that can be amended by amending the certificate of incorporation. See id. 
Furthermore, shareholders of a Delaware company will only have the right to call an interim shareholder meeting where the charter or bylaws authorize them to do so. ${ }^{266}$ In Germany, meanwhile, the supervisory board directors may be removed at any time without cause, but the removal threshold is a supermajority (75\%), making removal difficult in practice. ${ }^{267}$

Recent empirical work suggests that this predicted relationship between shareholder rights and the behavior of financial institutions is very real indeed. ${ }^{268}$ Ferreira, Kershaw, Kirchmaier, and Schuster construct a "management insulation index" (MII) and apply this index to all U.S. banks to measure the extent and variation in shareholder rights. ${ }^{269}$ They then regress MII index scores against, inter alia, data on which banks were bailed-out through the U.S. Troubled Asset Relief Program (TARP). ${ }^{270}$ TARP is viewed by the authors as a proxy for a bank's pre-crisis susceptibility to failure and an arguable proxy for excessive risk-taking. ${ }^{271}$ They find that banks which were less insulated were more likely to be bailed out. ${ }^{272}$ For Ferriera et al. the most compelling explanation for the relationship between managerial insulation and bank failure is that the banks which are subject to stronger shareholder rights would be more susceptible to shareholder pressure to take excessive risks and, therefore, more likely to fail. ${ }^{273}$ This generates what would be for many commentators and policymakers a counterintuitive result: for banks stronger, and not weaker, shareholder rights are a problem. ${ }^{274}$

For our purposes, this suggests that where directors of financial institutions are subject to powerful shareholder rights, then the ethical cultural objectives are likely to be subordinated. This effect will be more powerful when strong shareholder rights and pressure are combined with a corporate objective that prioritizes shareholder interests. ${ }^{275}$ However, even when a bank is subject to a multiple-interest rule, as Ferriera et al.'s U.S.

${ }^{266} I d . \S 211$ (d).

${ }^{267}$ Aktiengesetz [AktG] [Stock Corporation Act], Sep. 6, 1965, BGBl. I \& 103 (Ger.).

${ }^{268}$ See Daniel Ferreira et al., Shareholder Empowerment and Bank Bail Outs 24 (2012), available at $\mathrm{http}: / /$ papers.ssrn.com/sol3/papers.cfm?abstract_id=2170392.

${ }^{269}$ See id. at 5.

${ }^{270} \mathrm{See}$ id. at 13.

${ }^{271}$ See id. at 24.

${ }^{272}$ See Ferreira et al., supra note 268 , at 2.

${ }^{273} \mathrm{See}$ id. at 25.

${ }^{274}$ See Reint Gropp \& Matthias Köhler, Bank Owners or Bank Managers: Who is Keen on Risk? Evidence from the Financial Crisis 4 (European Bus. Sch., Research Paper No. 10-02, Feb. 23, 2010), available at http://papers.ssrn.com/sol3/papers.cfm?abstract_id=1555663 (taking a different approach but reaching some similar conclusions).

${ }^{275}$ See Gropp \& Köhler, supra note 274 , at 22. 
study shows, such rights may drive behavior that disregards non-shareholder concerns. ${ }^{276}$ It follows that where there are more powerful shareholder rights, managers' commitment to the implementation of the TCF, Extended TCF, and TES Initiatives is likely to be more muted, thus undermining their potential effectiveness. This suggests that to create space for norm formation through the TCF, Extended TCF, and TES Initiatives regulators will need to tack against the prevailing consensus that banks should be subject to stronger, not weaker, shareholder rights. ${ }^{277}$ It also suggests that, ceteris paribus, the U.S. and Germany provide more fertile soil for the initiatives than, for example, the U.K.

\section{E. Corporate Law: The Duty of Care}

We have considered the ways in which an ethical culture could be connected to remuneration and other governance arrangements which incentivize senior managers to commit to measures such as the TCF, Extended TCF, and TES Initiatives and to insulate them, to a degree, from pressures to pursue shareholder value. But as managerial leadership is central to the success of these strategies, we also need to consider the role that the threat of potential liability might play.

Imposing liability upon directors for failing to take due care in the implementation of the TCF, Extended TCF, and TES Initiatives would be one approach to incentivizing managerial leadership. ${ }^{278}$ At the same time, the well-trodden debate about the duty of care in the Anglo-American context shows that regulators need to be wary of imposing care expectations on directors. ${ }^{279}$ Where the standards are too high, directors will be fearful that carefully taken but unsuccessful decisions, or careful supervision that failed to identify non-compliant behavior, will ex-post and with the benefit of hindsight be judged unfavorably. ${ }^{280}$ As a result, directors may either refuse to serve or take an excessively risk-averse approach toward the generation, monitoring, and enforcement of the relevant processes, systems, and controls.

\footnotetext{
${ }^{276} \mathrm{See}$ Ferreira et al., supra note 268, at 25 .

${ }^{277}$ See Gropp \& Köhler, supra note 274, at 22.

${ }^{278}$ See Sants, supra note 260 ("Behaviour is influenced by leadership, strategy, decisions, incentives, controls and the threat of sanctions: deterrence.").

${ }^{279}$ See Bernard S. Black et al., Outside Director Liability, 58 STAN. L. REV. 1055, 1122-34 (2006).

${ }^{280}$ See John Armour \& Jeffrey N. Gordon, Systemic Harms and the Limits of Shareholder Value Part IV.G.1 (Oct. 2012) (on file with the authors).
} 
It is this policy concern that explicitly informs Delaware corporate law with its gross negligence standard for the duty of care. ${ }^{281}$ This standard is violated only where it can be shown that directors were "recklessly indifferent" to the interests of the corporation ${ }^{282}$ or, in relation to internal controls, that there was "a sustained or systematic failure of the board to exercise oversight-such as an utter failure to attempt to assure a reasonable information and reporting system exists . . . "2833 Perhaps, as John Armour and Jeffrey Gordon have recently argued, the policy concerns that underpin Delaware's duty of care jurisprudence are less weighty in economic contexts such as banking where risk-taking is necessary and socially desirable but where, simultaneously, such risk-taking threatens to generate significant negative externalities. ${ }^{284}$ In such contexts, dampening executive directors' incentives to take risks may represent a more defensible policy objective. ${ }^{285}$ For our purposes, if regulators make this election in favor of a more demanding standard of care, this could play a role in incentivizing managers to meaningfully engage with the TCF, Extend TCF, and TES Initiatives and, thereby, help foster a more ethical culture.

In the U.K., higher care standards are already in place, although the probability of their enforcement is generally thought to be very low. ${ }^{286}$ The U.K. standard of care is that of a hypothetical reasonable average director where if the actual director in question has above average skills and experience the hypothetical director is imbued with those above average skills and experience. ${ }^{287}$

It is worth briefly examining how the TCF, Extended TCF, and TES Initiatives could interact with this general standard. In order to understand

${ }^{281}$ See, e.g., Gagliardi v. Trifoods, Int'l, Inc., 683 A.2d 1049, 1052 (Del. Ch. 1996) ("[D]t is in the shareholders' economic interest to offer sufficient protection to directors from liability for negligence, etc., to allow directors to conclude that, as a practical matter, there is no risk that, if they act in good faith and meet minimal proceduralist standards of attention, they can face liability as a result of a business loss."). Note further in this regard that most Delaware corporations benefit from a complete liability waiver for duty of care violations which is permitted pursuant to section 102(b)(7) of the Delaware General Corporation Law. DEL. CODE ANN. tit. 8, § 102(b)(7) (2011).

${ }^{282}$ See In re Walt Disney Co. Derivative Litig., 907 A.2d 693, 750 (Del. Ch. 2005), reprinted in 31 DEL. J. CORP. L. 349, 418 (2006).

${ }^{283}$ Stone v. Ritter, 911 A.2d 362, 369 (Del. 2006); In re Citigroup Inc. S'holder Derivative Litig., 964 A.2d 106, 122 (Del. Ch. 2009); In re Caremark Int'l Inc. Derivative Litig, 698 A.2d 959, 971 (Del. Ch. 1996).

${ }^{284}$ See Armour \& Gordon, supra note 280, Part II.A.

${ }^{285}$ See id., Part I.

${ }^{286}$ See John Armour, Enforcement Strategies in U.K. Corporate Governance: A Roadmap and Empirical Assessment 21(European Corporate Governance Inst., Working Paper No. 106/2008, Apr. 2008), available at http://papers.ssm.com/sol3/papers.cfm?abstract_id=1133542.

${ }^{287}$ See Companies Act, 2006, $\$ 174$. 
the expectations generated by the care standard, recent Australian case lawapplying a reasonable average director standard ${ }^{288}$ - has begun to draw on the best practice guidance set forth in both corporate governance codes and trade association guidelines. ${ }^{289}$ These sources are used to identify the functions and context-specific expectations of directors when determining whether they have taken reasonable care. For example, in Australian Securities and Investments Commission (ASIC) v. Rich ${ }^{290}$ the court took into account observations on the roles of directors in U.K. reports on board composition regulation $^{291}$ and a report from the British Confederation of Industry on the responsibilities of British public companies. ${ }^{292}$ More recently, the court in $A S I C$ v. Healey ${ }^{293}$ drew on materials produced by the Australian Institute for Directors respecting the director's role vis-à-vis financial statements in order to understand the role and function of non-executive directors in relation to financial reports. ${ }^{294}$

Following the lead of these Australian cases, guidelines and rules about a director's function and role can be used by courts to flesh out the substantive content of the duty of care. It can be argued, therefore, that where the TCF, Extended TCF, and TES Initiatives place explicit obligations on executive directors to spearhead implementation, a failure to take such duties seriously - as a reasonable average director would take them-could expose directors to personal liability. Similarly, if the nonexecutive directors serving on our proposed ethics committee failed to perform their oversight role with due care, they could find themselves in breach of their care obligation.

Of course, in any jurisdiction where a high standard of care is adopted, the extent to which it would incentivize executive and nonexecutive directors to take their obligations under the TCF, Extended TCF, and TES Initiatives seriously will be a function not only of the standard of care and its interaction with the initiatives, but also of the probability that any breach will be enforced by either the company, a shareholder or, as is possible in Australia, by the regulator. However, it is beyond this article's scope to address these broader corporate law issues. Furthermore, even in jurisdictions where the standard of care is demanding and the probability of

\footnotetext{
${ }^{288}$ See Australian Corporations Act $\S 180$ (2001).

${ }^{289}$ See Austl. Sec. \& Inv. Comm'n v Healey [2011] FCA 717, ๆ 192 (Austl.) (2003).

${ }^{290} \mathrm{Id}$.

${ }^{291}$ See DEREK HIGGS, REVIEW OF THE ROLE AND EFFECTIVENESS OF NON-EXECUTIVE DIRECTORS 97-104 (2003), available at http://www.ecgi.org/codes/documents/higgsreport.pdf.

${ }^{292} \mathrm{See}$ [2003] NSWC 85, Tा 69-71.

${ }^{293} \mathrm{See}$ [2011] FCA 717, ๆึ 194-96.

${ }^{294}$ See id. ๆ 194.
} 
enforcement high, one would not expect to see many cases where directorswhether executive or non-executive - are found personally liable. ${ }^{295}$ Indeed, actual director liability is very rare in all jurisdictions. ${ }^{296}$ Of course, this does not mean that the threat of liability would not influence behavior. ${ }^{297}$

\section{CONCLUSION}

There is little doubt that, for better or worse, culture and ethics play an important role in the governance of financial services firms. ${ }^{298}$ There is less consensus, however, surrounding the question of whether, or to what extent, the law or markets can (or should) be utilized to generate meaningful cultural and/or ethical constraints in pursuit of broader social objectives. ${ }^{299}$ When financial markets were on a seemingly endless upwards trajectory, the question was not a pressing one. In the wake of the GFC, however, it has justifiably been the subject of renewed focus.

This paper has canvassed some of the ways which we might seek to engender a more ethical culture within the financial services industry. ${ }^{300}$ More specifically, it has illustrated how process-oriented regulation, combined with more radical restructuring of the internal governance arrangements of financial institutions, could be leveraged to achieve this laudable objective. Ultimately, however, there are no easy answers; no quick fixes. Nevertheless, public support from across the political spectrum, along with the stated commitment of financial leaders themselves, has created the opportunity for reform, and it should be taken.

${ }^{295}$ Even in Australia, where these two preconditions are arguably applicable - particularly because ASIC has the power to enforce breaches of duty - we still do not see higher levels of director liability. In $A S I C$ v. Healey for example, although the directors were found in breach, no financial penalty was imposed upon them. See [2011] FCA 717, 9583 (finding directors liable for failing to take reasonable steps to read and understand financial statements). But see Austl. Sec. \& Inv. Comm'n v Healey (No. 2) [2011] FCA 1003, In 190-91 (Austl.) (holding the majority of directors financially liable only for the plaintiffs costs incidental to the proceeding).

${ }^{296}$ See Black et al., supra note 279 , at 1059-60.

${ }^{297}$ Both positively in ensuring that the TCF, Extended TCF, and TES Initiatives are taken seriously and negatively insofar as skilled executive and non-executive directors refuse to serve.

\footnotetext{
${ }^{298}$ See supra Part III.C.

${ }^{299}$ See supra Part IV.

${ }^{300}$ See supra Part V.
} 